\title{
Sorotan Dialek di Terengganu Selepas Tiga Dekad: Perspektif Geolinguistik
}

\author{
Nor Hashimah Jalaluddin ${ }^{a}$ \\ shima@ukm.edu.my \\ Pusat Kajian Bahasa dan Linguistik, \\ Universiti Kebangsaan Malaysia, Malaysia \\ Wan Athirah Adilah Wan Abdul Halim \\ p103364@siswa.ukm.edu.my \\ Pusat Kajian Bahasa dan Linguistik \\ Universiti Kebangsaan Malaysia, Malaysia \\ Harishon Radzi \\ naslin@ukm.edu.my \\ Pusat Kajian Bahasa dan Linguistik \\ Universiti Kebangsaan Malaysia, Malaysia
}

\begin{abstract}
ABSTRAK
Kajian dialek yang dulunya bersifat tradisional dengan mencari perbezaan fonologi, telah berkembang menjadi kajian geografi, sejarawi dan sumber data kajian teoritis. Hari ini kajian dialek telah melalui inovasi dengan mensinergikan teknologi dalam penghuraian isoglos dan memasukkan elemen bukan linguistik dalam memberi penjelasan kepada penyebaran dialek itu sendiri. Demi kelangsungan ilmu ini, usaha mengisi kelompangan penyorotan kajian dialek dengan mengkhususkan kepada dialek Terengganu telah dilakukan. Dialek ini pernah dihuraikan tiga dekad yang lalu dan pastinya memerlukan input baharu. Kajian ini bermatlamat menyelidiki semula ciri dialek Terengganu, menghasilkan garis isoglos yang memisahkan dialek Terengganu dan Kelantan serta membuktikan kedominanan dialek ini di sepanjang pantai timur. Kajian ini merupakan kajian lapangan yang melibatkan 500 orang penutur dengan 64 titik kampung. Ia melibatkan warga tua, dewasa dan remaja. Kesemua responden diminta membunyikan empat puluh leksikal terpilih berdasarkan senarai Swadesh di samping temu bual untuk mendapatkan bunyi yang tepat. Hasil kajian mendapati kesemua ciri fonologi kekal seperti tiga dekad dahulu cuma input fonetik dan rumus fonologi telah dikemaskan bagi menepati piawai linguistik. Keduanya, isoglos yang tepat yang membatasi dialek Terengganu dan Kelantan telah berjaya dipetakan beserta titik kampung yang tepat. Akhirnya memang wujudnya rantaian atau kontinum dialek Terengganu di sepanjang pantai timur dari Setiu Laut hingga ke Kota Tinggi di Johor. Ketersebaran dialek ini di sepanjang jalur kawasan pantai timur diperkuatkan lagi dengan faktor topografi, sejarah dan sosio-budaya. Kajian sorotan ini telah menambah baik deskripsi dialek Terengganu berasaskan perspektif geolinguistik dan sekali gus membuktikan pendekatan multidisiplin dapat menghuraikan dialek ini dengan lebih sistematik.
\end{abstract}

Kata kunci: dialek Terengganu; geolinguistik; isoglos; sorotan dialek; rantaian dialek

${ }^{a}$ Penulis utama \& koresponden 


\title{
Dialect Revisited in Terengganu After Three Decades: A Geolinguistic Perspective
}

\begin{abstract}
The study of dialects, which used to be traditional through the search of phonological differences, has evolved into a geographical study, historical study, and theoretical data sources. Today dialect studies have undergone innovations by synergizing technology in isogloss descriptions and incorporating non-linguistic elements in explaining the spread of the dialect itself. For the sake of this knowledge's continuity, efforts to fill the void of the study of dialect by specializing in the Terengganu dialect have been made. This dialect was once described three decades ago and certainly needed new input. This study aims to re-investigate the Terengganu dialect features, produce isogloss lines that separate the Terengganu and Kelantan dialects and prove this dialect's dominance along the east coast. This study is a field study involving 500 speakers with 64 village points. It involves the elderly, adults and adolescents. All respondents were asked to pronounce forty selected lexicals based on the Swadesh list in addition to interviews to obtain accurate sounds. The study results found that all phonological features remained the same three decades ago; only phonetic inputs and phonological rules were refined to meet linguistic standards. Secondly, the exact isogloss limiting Terengganu and Kelantan's dialects have been successfully mapped along with the exact village points. Finally, there is a chain or continuum of the Terengganu dialect along the east coast from Setiu Laut to Kota Tinggi in Johor. Topographic, historical and socio-cultural factors further strengthen the spread of this dialect along the east coast area. This study has improved the Terengganu dialect description based on the geolinguistics perspective, proving that a multidisciplinary approach can systematically describe this dialect.
\end{abstract}

Keywords: Terengganu dialect; geolinguistics; isogloss; dialect revisited; dialect continuum

\section{PENDAHULUAN}

Ilmu sentiasa berevolusi. Selalunya evolusi itu mengikut situasi semasa dan wujudnya keperluan untuk menambah baik apa yang telah dihasilkan. Semua ilmu tidak kira dari bidang sains dan sains sosial perlukan pemugaran agar ilmu terus berkembang. Salah satu caranya adalah dengan melakukan penilaian semula atau sorotan (revisited). Contohnya, penilaian semula pernah dilakukan pada Situational Leadership Theory oleh Hersey dan Balnchard (1996) dalam artikel 'Revisiting the life-cycle theory of leadership'. Mereka menilai kembali cara pengurusan berdasarkan initiating structure (task) dengan consideration (relationship). Mereka telah membicarakan gaya kepimpinan dari menekankan tentang kematangan ketua dan pekerja berubah ke arah kepimpinan mengikut situasi berkonsepkan 'sedia, mahu, dan mampu' . Ciri kemahuan dan kebolehan berinteraksi untuk menentukan kesediaan seseorang, manakala ciri kemahuan dan kemampuan berinteraksi pula untuk menentukan kesediaan seseorang. Ini bagi menjamin keharmonian bekerja dalam satu-satu organisasi. Situational Leadership Theory (SLT) ini kemudiannya disoroti semula oleh Thompson G. \& Robert P. V. (2009). Kali ini SLT dikritik oleh ahli akademik kerana kekurangan data empirikal. Empat penilaian semula dilakukan dengan menggunakan konsep SLT - dalam kalangan guru, petugas kesihatan, pengurusan universiti dan pengurusan tentera. Kesemua organisasi ini memberikan pandangan yang berbeza mengenai konsep hubungan majikan dan pekerja. Hasil penilaian semula, maka terhasil SLT versi baharu.

Hal yang sama turut dilihat dalam kajian linguistik. Penilaian teori-teori terdahulu telah menghasilkan teori-teori terkini. Contohnya, kajian semantik di peringkat awal tidak 
memasukkan konteks dalam ilmu makna. Ini menjadikan kajian makna terhad kepada bentuk harfiah sahaja kerana ahli falsafah berpendapat kajian makna dengan memasukkan konteks termasuk dalam ruang lingkup kajian ahli falsafah (Bloomfield, 1950). Kemudian ilmu semantik mengalami banyak penilaian semula sehinggalah lahirnya beberapa teori baharu menggantikan semantik falsafah seperti Relevance Theory (1995) oleh Sperber dan Wilson yang memasukkan konteks dalam kajian makna. Begitu juga halnya dengan kajian dialek. Kajian dialek bermula seawal 1881 oleh Wenker di Jerman dan Gillieron 1896 (Nor Hashimah et al., 2019). Kajian dialek tradisional ini ingin membentuk isoglos dialek bagi setiap daerah kajian. Wenker telah menggunakan kaedah perkhidmatan pos bagi mengumpul dialek yang ditinjau. Kelemahan kajian Wenker dibaiki oleh kajian Gillieron dengan menggunakan khidmat Edmond Edmont yang berbasikal ke seluruh Perancis bagi mengutip data dialek. Di sini, sorotan semula pada kajian dilakukan sehingga membawa kepada metodologi yang lebih baik. Melalui evolusi masa dan sorotan semula metodologi kajian tersebut, maka lahirnya kajian dialek yang lebih holistik yang menggabungkan maklumat linguistik, topografi, sejarah dan sosio-budaya seperti dalam kajian geolinguistik (Fukushima, 2016; Mitsuaki, 2018; Nor Hashimah et al., 2016; Nor Hashimah et al., 2017; Nor Hashimah et al., 2019)

Dalam konteks pengkajian dialek di Malaysia, sorotan memang berlaku bagi memberi nafas baharu pada ilmu dialek itu sendiri. Dari sorotan yang dilakukan, maka berlaku pertambahan maklumat bagi memperkayakan kajian dialek yang terdahulu. Bermula dengan penghasilan peta isoglos oleh Ismail Hussin (1973) kemudian ditambah baik oleh Asmah $\mathrm{Hj}$. Omar (1976). Asmah (1976) telah memberikan penentuan isoglos yang lebih terperinci, iaitu daripada lima (5) garis isoglos bertukar menjadi tujuh (7). Kajian dialek tradisional di Malaysia diwarnai pula dengan kajian dialek geografi yang lebih fokus kawasan kajiannya seperti yang dilakukan oleh Collins (1983). Malah ada yang menjadikan data dialek sebagai sumber seperti kajian Zaharani (1993) dan Nur Adibah dan Sharifah Raihan (2017). Terkini adalah kajian dialek dan teknologi yang memanfaatkan Geography Information System (GIS) sebagai peranti untuk memberikan titik kampung dengan tepat beserta maklumat topografi yang membantu menjelaskan taburan dialek dengan sistematik (Nor Hashimah et al., 2016; Nor Hashimah et al., 2017; Zaharani, Nor Hashimah \& Yusmaniza, 2018; Nor Hashimah et al., 2019; Nor Hashimah et al., 2020). Bagi mengintergrasikan semua kajian di atas, satu sorotan semula akan diadakan pada dialek di seluruh Terengganu khususnya berasaskan kajian yang telah diadakan tiga dekad lalu. Kajian umum yang dilakukan oleh Asmah (1985), dan Collins (1983) tentang dialek Terengganu dapat dikemaskan lagi dengan kajian terkini berasaskan perspektif geolinguistik. Objektif kajian ini adalah untuk meneliti semula varian fonologi yang dikatakan menjadi ciri dialek Terengganu, pemplotan isoglos terkini yang menjadi sempadan dialek di antara dialek Terengganu dan dialek Kelantan dan akhirnya menghuraikan sejauh mana dominasi dialek Terengganu di Pantai Timur. Sorotan semula ini akan menggunakan perspektif geolinguistik yang akan mengintegrasikan linguistik, GIS, maklumat topografi, sejarah, ekonomi dan sosio-budaya.

\section{SEJARAH TERENGGANU}

Sebelum menyorot tentang dialek Melayu di Terengganu, elok kita teliti dahulu sejarah negeri Terengganu. Sejarah ini sedikit sebanyak akan memberi input kepada pemahaman kita mengenai Terengganu. Negeri Terengganu terbahagi kepada 7 daerah, iaitu Kemaman, Dungun, Marang, Kuala Terengganu, Hulu Terengganu, Setiu dan Besut. Penemuan batu bersurat di Hulu Terengganu, dengan tanggal 702 Hijrah (bersamaan 1303 Masihi) terpahat padanya telah menunjukkan bahawa masyarakat Terengganu sudah berubah dan maju satu tahap lagi dengan penerimaan tamadun baru iaitu Islam. Islam telah bertapak paling lewat sejak 
awal abad ke 14, menjadikan Terengganu sebagai salah sebuah negeri yang paling awal menerima Islam di Malaysia (Abdullah Rahman Embong, 2012).

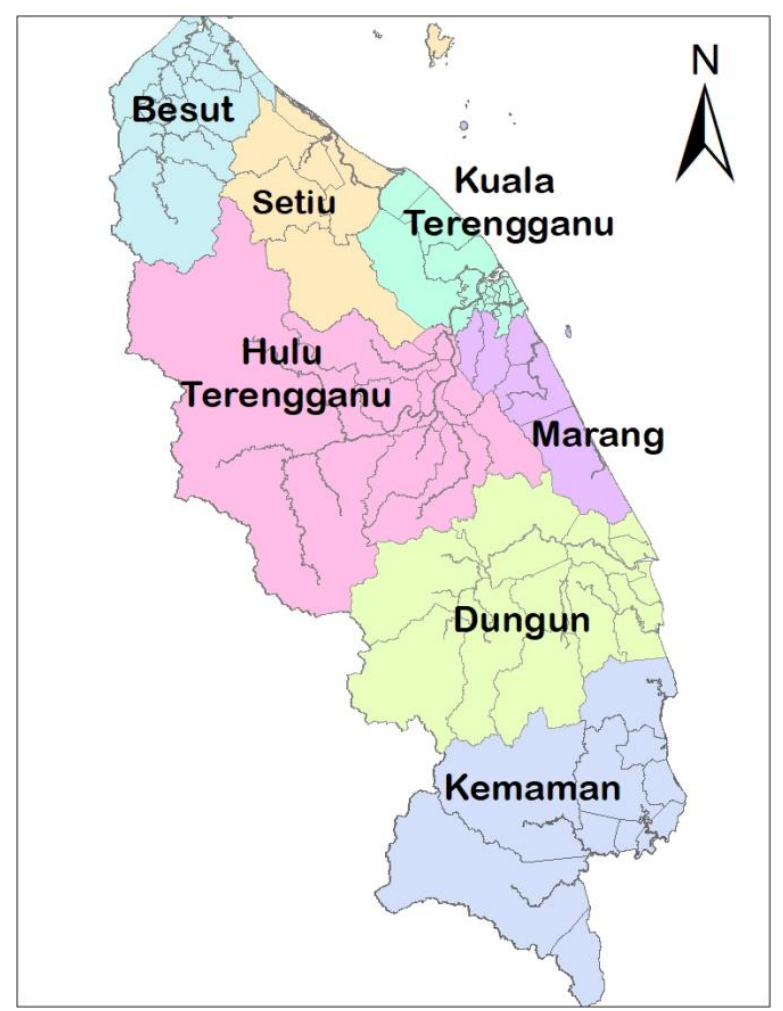

Sumber: FRGS/1/2019/SSI01/UKM/01/1 menggunakan Geography Information System (GIS)

PETA 1. Peta Negeri Terengganu

Negeri Terengganu termasyhur dengan sejarahnya sehingga digelar sebagai 'Warisan Pesisir Air' yang mendukung moto 'Negeri Cantik Budaya Menarik' mempunyai justifikasi dan rasional tentang keunikan dan keistimewaan khazanah alam, masyarakat, budaya, dan bahasanya. Negeri Terengganu yang kaya dengan hasil petroleum mampu menjadikan Terengganu sebuah negeri yang terkenal dengan hasil buminya. Selain itu, perkembangan bahasa dari kelompok pantai timur ini menunjukkan bahawa Malaysia kaya dengan variasi dialeknya.

Pada abad ke-19, ibu negeri dan pusat pentadbiran Terengganu ialah Kuala Terengganu. Pada tahun 1828 jumlah penduduknya kira-kira 30,000 orang. Menurut Medhurt (dalam Abdullah Zakaria, 1984), yang melawat Kuala Terengganu pada tahun 1828 (iaitu lebih dahulu dari lawatan G.W. Earl) Kuala Terengganu adalah sebuah bandar Melayu yang ramai penduduknya dan jalan-jalannya yang sempit serta kawasannya kotor. Di Kuala Terengganu terdapat juga orang-orang Cina tetapi jumlah mereka tidaklah ramai, dan kebanyakan dari mereka ini menetap di Kampung Cina. Mereka ini berketurunan Hokkien dan Kheh. Pekerjaan mereka ialah berniaga. Jumlah mereka kira-kira 600 orang. Mereka memiliki jong (junk) sendiri dan mengadakan perdagangan dengan negeri-negeri Siam, Kemboja, Tongkin dan Sambas. Kuala Terengganu juga adalah pusat perdagangan yang terbesar di Terengganu yang mana sentiasa dikunjungi oleh pedagang-pedagang dari rata-rata Semenanjung Tanah Melayu, Kepulauan Melayu dan Eropah.

Sistem perhubungan yang penting di Terengganu pada abad ke-19 ialah sungai dan pesisiran pantai. Oleh sebab itu, rumah-rumah di kawasan pedalaman didirikan berhampiran dengan sungai; manakala kawasan pinggir pantai pula, rumah-rumah didirikan berhampiran 
pantai. Penempatan mereka ini mempunyai hubungan erat dengan kemudahan hubungan di antara satu tempat dengan tempat yang lain. Biasanya, penduduk-penduduk di dalam sesebuah kampung itu adalah terdiri daripada mereka yang mempunyai tali persaudaraan.

Sebelum pengasasan kesultanan Terengganu di bawah Tun Zainal Abidin, dan penempatan rombongan dari Johor-Riau dan Patani yang mendampingi baginda, pada awal Kurun ke 18, wilayah tersebut bukanlah suatu kawasan kosong (no man's land). Jalur-jalur kehidupan yang berkembang berikutan pertapakan kerajaan baru kini adalah kesinambungan daripada perkembangan manusia sebelumnya. Lama sebelum kemunculan Melaka sebagai kerajaan dan empayar pada kurun ke 15 dan 16, Telanai dan keturunannya, di samping para 'megat', sudah pun merupakan penguasa tempatan, dengan penyokong dan pengikutnya. Komuniti manusia sebelum Megat Panji Alam dan Megat Kembar Ali yang sezaman dengan Hang Tuah dan Hang Jebat telah pun menempa kehidupan. Malah penempatan di Terengganu dipercayai bermula beribu tahun dahulu lagi. Penemuan gendang Dong Son berusia 2000 tahun di Batu Buruk dan Jertih, sebagaimana penemuan pecahan tempayan dan pasu di Kenyir, menunjukkan kehadiran manusia pra sejarah di kawasan berkenaan yang berkemungkinan berhubungan dengan China dan Vietnam. Di sepanjang zaman, pangkalan dan perkampungan di pesisiran pantai berangkaian dengan pusat-pusat kuasa luar seperti Funan, Ayudhya dan Majapahit. Sama ada mereka ini 'Orang Melayu Jati' (yang disebut Deutero-Malays) atau pendatang luar sukar untuk ditentukan. Orang asli, sama ada Sakai atau Semang, juga mendiami beberapa pelosok bumi Terengganu.

Pada kurun ke-14, muncul komuniti manusia di Kuala Berang, sebuah pelabuhan dan pusat perdagangan, dengan ciri-ciri maritim dan kosmopolitannya, sehingga membawa kepada peristiwa Batu Bersurat (Muhammad Abu Bakar, 2018). Berdasarkan penemuan-penemuan ini, jelas menunjukkan Terengganu mempunyai tamadun yang tinggi sehingga menjadi tarikan daripada orang luar untuk menetap di Terengganu. Ertinya, ketika Melaka sedang berkembang dan mengukir nama di persada dunia global semasa, kawasan tersebut dan juga Kuala Terengganu, dengan rujukan dan gelaran berbagai-bagai yang diberi kepadanya termasuk 'Primula', sudah pun mempunyai penghuni yang agak ramai, dengan Islam menjadi anutan mereka.

\section{KOSA ILMU}

Menurut Asmah Hj Omar (1985), dialek sebagai satu sub-bahasa yang mewakili satu bahasa tuturan sesebuah penduduk di satu-satu kawasan. Collins (1983) pula mentakrifkan dialek sebagai satu ragam bahasa yang dibezakan secara tegas daripada ragam-ragam lain berdasarkan ciri-ciri penyebutan, kosa kata, dan tatabahasa. Kajian dialek ini ternyata memberi sumbangan kepada bidang linguistik khususnya dalam aspek pemetaan kawasan yang menggunakan dialek sebagai data. Hal ini menunjukkan bahawa dialek di Malaysia mempunyai keunikan dan ciriciri yang tersendiri namun pada masa yang sama, dialek-dialek ini mempunyai darjah kesalingfahaman yang tinggi. Sehubungan dengan itu, kajian ini akan menyorot kembali kajian dialek khususnya di Terengganu selepas 35 tahun. 35 tahun itu adalah berasaskan deskripsi dan isoglos yang dikemukakan oleh Asmah Hj Omar (1985).

Kosa ilmu merupakan bahagian yang penting dalam penulisan ilmiah. Kosa ilmu akan memandu penulis mencari kelompangan kajian dan seterusnya mencari jalan untuk mengisi kelompangan itu. Dalam artikel ini, kosa ilmu akan dibahagi kepada dua, iaitu kosa ilmu mengenai usaha-usaha sorotan semula kajian dialek oleh sarjana luar dan tempatan. Kemudian diikuti dengan deskripsi khusus tentang dialek Terengganu yang ditulis oleh Collins (1983) dan Asmah (1985) lebih tiga (3) dekad dahulu. Kajian Collins telah disoroti oleh Nasrun dan Collins (2017) dan kajian Asmah telah disoroti oleh Ajid (2008). Dari sorotan yang ada, kajian ini akan memerihalkan lagi dialek Terengganu berasaskan perspektif geolinguistik. 
Kajian sorotan semula dialek pernah dilakukan pada dialek di Tibet dan di Vietnam. Suzuki (2012) menulis tentang 'Tibetan pigs revisited: Multiple piglets with a sow in Yunnan Tibetan and beyond'. Suzuki (2012) telah memplot semula peta dialek yang lama berdasarkan perkataan 'sow' dan 'piglet' dalam dialek Yunnan Tibet. Pemplotan menggunakan ArcGis khususnya koroplet mampu memberikan maklumat taburan kedua-dua leksikal ini dengan lebih tepat berbanding dengan pemplotan isoglos secara tradisional. Usaha yang sama dapat dilihat pada kajian Shimizu Masaaki (2016). Masaaki (2016) telah menilai semula dialek Vietnam berdasarkan penulisan dua puluh tahun dahulu. Masaaki (2016) telah memplot semula isoglos dialek di Vietnam yang dibahagi kepada tiga oleh Hoàng Thi Châu (1989). Dengan bersandarkan pada data yang dikutip pada 2011-2012, Masaaki (2016) telah menemui dapatan baharu. Dapatan kajian menunjukkan berlaku perubahan fonologi pada bunyi konsonan dengan rima mudah, (contoh: /-a / dan /-o/), rima dengan bunyi awalan mudah seperti (/t-/, /k-/), dan 6 nada pada suku kata terbuka, /ta/, serta perubahan dalam ayat (Anh Hà co thê đà hen). Kajian awal oleh Hoàng Thi Châu (1989) telah membahagikan dialek di Vietnam ini kepada dialek UTARA, TENGAH dan SELATAN, tetapi hasil sorotan dan revisi terkini mendapati sempadan dialek di antara UTARA dan SELATAN telah menjadi kabur berbanding 20 tahun dahulu. Walau bagaimanapun, sempadan dialek di antara UTARA dan TENGAH masih jelas yang menjadikan status dialek UTARA menjadi dominan sehingga membolehkan dialek UTARA menyebar ke bahagian TENGAH dan SELATAN.

Satu sorotan dari kajian Adelaar pada tahun 1992 mengenai Melayu Purba dengan himpunan data dari Hulu Tembeling pernah dilakukan oleh Mohd Tarmizi Hasrah, Shahidi A. H. \& Rahim Aman (2013). Mereka menulis tentang 'Inovasi dan Retensi dalam Dialek Hulu Tembeling dan membincangkan satu ciri inovasi dan retensi dalam dialek Hulu Tembeling iaitu perubahan segmen bunyi yang terjadi pada konsonan nasal akhir dan pengekalan vokal tinggi pada posisi suku kata praakhir. Kajian mengenai dialek Hulu Tembeling telah dibandingkan dengan bahasa Malayik Purba (MP) yang telah direkonstruksi oleh Adelaar terlebih awal dari Tarmizi et. al (2013). Ciri inovasi DHT yang ditemui ialah monoftongisasi konsonantal yang merupakan proses lanjutan daripada diftongisasi; manakala, ciri retensi DHT ialah pantulan linear vokal tinggi MP, *i dan *u pada posisi awal kata. Pendeskripsian ciri inovasi dan retensi dilanjutkan dengan mencuba untuk menyingkap faktor yang mempengaruhi kewujudannya yang dianggap sebagai ciri sewilayah antara DHT dengan dialek Hulu Terengganu. Anggapan mengenai ciri sewilayah membolehkan DHT dikelompokkan secara bersama dengan dialek Hulu Terengganu. Selain itu, mereka turut menyentuh mengenai ketidakstabilan DHT disebabkan sentiasa menunjukkan perubahan. Akhir sekali, ditampilkan suatu kemungkinan akan kewujudan rantaian dialek di seluruh lembangan Sungai Pahang berdasarkan bukti yang memperlihatkan perendahan vokal yang simeteris. Tentunya disedari bahawa dengan hanya satu ciri inovasi dan retensi tidak mungkin suatu kesimpulan saksama dapat diutarakan. Walaupun kesedaran tersebut muncul, namun tetap diyakini bahawa DHT memberikan suatu maklumat awal tentang kemungkinan penambahbaikan pengelompokan dan penjejakan rantaian dialek-dialek di pantai timur.

Dari tiga sorotan di atas terbukti bahawa kajian dialek ini boleh dinilai semula dengan tujuan penambahbaikan. Banyak data baharu yang ditemui dan dapat mengubah deskripsi sesuatu dialek pada hari ini. Penambahan maklumat baharu pastinya menjadikan deskripsi dialek lebih sempurna dan menarik.

Secara umumnya, ada beberapa kajian dialek yang telah dilakukan di Terengganu. Sebelum menyorot kajian oleh Asmah (1985), Collins (1983) dan Ajid (2008), kita teliti dulu kajian lain yang berkaitan dialek Melayu di Terengganu. Kajian sosiolinguistik pernah dilakukan oleh Normaliza Abd Rahim, Noraien Mansor dan Noor Rohana Mansor (2014). Kajian mereka meninjau pilihan bunyi vokal pada leksikal yang disenaraikan. Kajian yang bertajuk 'Perbualan Masyarakat Daerah Kuala Terengganu' telah menganalisis perbualan 
kedai kopi dalam kalangan masyarakat di salah satu daerah negeri Terengganu. Keputusan kajian mendapati bahawa informan lebih selesa menggunakan dialek daerah Kuala Terengganu, iaitu penggunaan akhiran [a] bertukar kepada [ə] yang banyak digunakan dalam perbualan. Sebagai contoh, [adə], [limə], [kitə], [duwə] digunakan berbanding dengan bahasa Melayu Standard iaitu [ada], [lima], [kita], [duwa]. Informan berpendapat tanpa penggunaan bunyi [ə], bunyi perkataan akan menjadi sumbang dan tidak difahami oleh orang lain. Manakala Nur Adibah Hasan dan Sharifah Raihan Syed Jaafar (2017) melihat dari perspektif teoritis mengapa wujudnya bunyi 'ng' [y] di akhir perkataan seperti ‘ikan' menjadi [ikay] dan mengapa berlakunya pengguguran suku kata dari tri suku kata ke dwi suku kata. Contohnya dari 'kenapa' menjadi 'napa', 'begini' bertukar 'gini' dan 'berapa' menjadi 'bape'. Analisis dilakukan menggunakan teori fonologi Optimaliti.

Untuk tujuan sorotan, artikel ini akan berasaskan kepada kajian Asmah (1985), Collins (1983) dan Ajid (2008). Terdahulu, Asmah Hj. Omar (1976) yang menggunakan kaedah yang sama dengan Ismail Husin (1973) dari segi persamaan kesejajaran fonologi telah mengelompokkan dialek-dialek Melayu kepada lima (5) kelompok iaitu: Kelompok Barat Daya-Kedah-Perlis-Pulau Pinang-Perak Utara; Kelompok Timur Laut-Kelantan; Kelompok Timur-Terengganu; Kelompok Selatan-Johor-Melaka-Pahang-Selangor-Perak Selatan; dan Negeri Sembilan. Lanjutan daripada kajian ini, Asmah (2008) telah memperincikan pengelompokan dialek kepada tujuh (7) kumpulan berdasarkan perbandingan aspek-aspek fonologi iaitu: Pertama, Dialek Barat Laut yang dikenali umum sebagai dialek Utara-PerlisKedah-Pulau Langkawi-Pulau Pinang-Perak Utara sehingga Taiping; Kedua, Dialek Perak Kawasan Perak Tengah; Ketiga, Dialek Selatan - Perak Selatan-Selangor-Melaka-Johor; Keempat, Dialek Kelantan - Kelantan-Sempadan Pahang dan Terengganu; Kelima, Dialek Terengganu; Keenam, Dialek Pahang; dan Ketujuh, Dialek Negeri Sembilan. Pembahagian kelompok dialek oleh Asmah telah meletakkan Terengganu dalam kelompok dialek tersendiri.

Melalui buku 'Susur Galur Bahasa Melayu' (1985), kajian dialek Terengganu oleh Asmah boleh dianggap ekstensif. Asmah (1985) telah membandingkan subdialek Hulu Telemong dengan subdialek-subdialek yang lain di Terengganu. Antara subdialek yang lain termasuklah, subdialek Kuala Terengganu, Hulu Nerus, Kuala Jerangau dan Kuala Jelai.

Contohnya:

JADUAL 1. Senarai Leksikal Dialek Terengganu (Asmah, 1985)

\begin{tabular}{|c|c|c|c|}
\hline $\begin{array}{c}\text { Kuala } \\
\text { Terengganu } \\
\end{array}$ & Hulu Terengganu & Hulu Nerus & $\begin{array}{l}\text { B. Melayu } \\
\text { Standard }\end{array}$ \\
\hline [dzalay] & [d]aley] & [d]alẽ $]$ & [dzalan] \\
\hline [makay] & [makey] & {$[\mathrm{mak} \tilde{\varepsilon}]$} & [makan] \\
\hline [hitay] & [hitey] & [hitẽ $]$ & [hitam] \\
\hline Kuala Jerangau & \multicolumn{2}{|c|}{ Kuala Jelai } & B. Melayu Standard \\
\hline [suya] & \multicolumn{2}{|c|}{$[\operatorname{sun} \varepsilon]$} & [suyaj] \\
\hline [kəda] & \multicolumn{2}{|c|}{$[\operatorname{kod} \varepsilon]$} & [kədaj] \\
\hline
\end{tabular}

Kesimpulannya, dalam kajian Asmah $\mathrm{Hj}$. Omar (1985) yang berkaitan dengan kajian dialek Terengganu, beliau telah memaparkan varian leksikal yang dibunyikan atau dihasilkan mengikut kawasan. Asmah telah mendeskripsikan juga ciri-ciri fonologi yang ada pada dialek Terengganu seperti sistem vokal (monoftong dan vokal rangkap) dan konsonan (perubahan bunyi mengikut daerah artikulasi). Kajian dialek ini telah dilanjutkan oleh pengkaji-pengkaji lain bagi meluaskan dan meneliti dialek Terengganu. 
Selain Asmah, Collins pernah menghasilkan monograf, 'Dialek Hulu Terengganu' (1983). Kemudian kajiannya ditulis semula melalui 'Kajian Diftong dan Diftongisasi Dialek Hulu Terengganu' dalam buku Khazanah Dialek Melayu (1996). Collins telah membincangkan penelitian subdialek Hulu Terengganu dalam aspek fonologi iaitu diftongisasi. Kajian ini boleh dikatakan sebagai kajian dialek geografi kerana menumpukan khusus pada Hulu Terengganu. Collins ingin membuktikan bahawa dialek di Hulu Terengganu adalah berbeza dengan dialek Terengganu secara umumnya. Kajian ini dijadikan sandaran bagi melihat fenomena fonologi yang berlaku dalam dialek Hulu Terengganu. Ini dibuktikan dengan wujudnya proses diftongisasi pada leksikal yang berakhir dengan vokal. Collins berpendapat, sepatutnya dialek Hulu Terengganu dianggap salah satu dialek dalam kelompok dialek Semenanjung Timur. Maksudnya, hubungan antara dialek Hulu Terengganu dengan dialek Terengganu Pantai tidak erat berbanding dengan hubungan dialek Hulu Terengganu dengan dialek Kelantan. Dialek Hulu Terengganu bukan sebagai subdialek Terengganu; hubungannya boleh dianggap sejajar. Jadual 2 di bawah adalah contoh berlakunya diftongisasi pada suku kata terbuka dialek di Hulu Terengganu.

JADUAL 2. Perkataan diftongisasi di Hulu Terengganu oleh J.T. Collins (1983)

\begin{tabular}{|c|c|c|c|c|c|c|}
\hline $\begin{array}{l}\text { Bahasa } \\
\text { Melayu }\end{array}$ & Pereh & $\begin{array}{c}\text { Tanjung } \\
\text { Putat }\end{array}$ & Telaga & $\begin{array}{c}\text { Tanjung } \\
\text { Baru }\end{array}$ & Peneh & Ulu Sat \\
\hline $\mathrm{abu}$ & abtw & abuw $^{h}$ & $a b u^{<} w$ & $a b a^{\prime} w$ & abəw? & abəw $w^{k}$ \\
\hline aku & aktw & akuw $^{\text {h }}$ & $a k u^{<} w$ & aka’w & akəw? & akəw ${ }^{k}$ \\
\hline sembilu & mîluw & səmĩluw ${ }^{h}$ & səmĩlu ${ }^{<} w^{h}$ & səmĩlu’w & smĩləw? & $m: l \partial w^{k}$ \\
\hline garu & gaytw & gayuw $^{h}$ & (ukeə) & gaya<w & gayəw? & gayəw $^{k}$ \\
\hline bulu & bultuw & buluw $^{\text {h }}$ & bulu<w & bula’w & buləw & buləwk \\
\hline kayu & kayuw & kayuw $^{\text {h }}$ & kayu ${ }^{<} w$ & kaya’w & kayəw & kayəwk \\
\hline batu & battw & batuw $^{\text {h }}$ & batu<w & bata'w & batəw & batəwk \\
\hline beli & boliy & baliy ${ }^{h}$ & boliy & bəla<y & bələy & bala $y^{k}$ \\
\hline kiri & kijiy & kiyìy & kiyiy & kija<y & kiүәу & 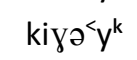 \\
\hline mati & mãtiy & mãtiy ${ }^{h}$ & mãtiy & mãta<y & mãtəy & mãtə< $y^{k}$ \\
\hline laki & lakìy & lakiy ${ }^{h}$ & lakiy & laka<y & lakəy & lak $\partial^{<} y^{k}$ \\
\hline kaki & kakiy & kakíy & kakiy & kaka<y & kakəy & kakə< $y^{k}$ \\
\hline hati & atiy & ativ $^{h}$ & atiy & $\operatorname{ata}^{<} y$ & atəy & at $\partial^{<} y^{k}$ \\
\hline mimpi & mĩpiy & mĩpiy ${ }^{h}$ & mĩpiy & mĩpa<y & mĩрәу & mĩрәуk \\
\hline
\end{tabular}

Kajian menunjukkan dialek Hulu Terengganu mempunyai keunikan dalam aspek diftongisasi mengikut beberapa kawasan. Dengan istilah suku kata terbuka iaitu perkataan berakhir dengan vokal membenarkan diftongisasi. Sebagai contoh, perkataan 'aku' yang bersifat monoftong, berubah menjadi diftong apabila penutur di Peneh menyebut sebagai [akəw?].

Selain Asmah dan Collins, Ajid Che Kob (2008) telah menulis mengenai 'Subklasifikasi Dialek Melayu Patani-Kelantan-Terengganu: Satu Analisis Kualitatif'. Kajian Ajid berbentuk sorotan daripada kajian Ismail Husin (1973) Asmah (1976) dan Asmah (1985). Menurut Asmah (1985) dan Collins (1996) khususnya wahana komunikasi masyarakat Melayu di Terengganu terdiri daripada tiga varian dialek, iaitu dialek Terengganu Pantai yang dituturkan hampir di semua daerah kecuali sebahagian Setiu, Besut dan Hulu Terengganu; dialek Kelantan yang dituturkan di Setiu dan Besut; dan dialek Hulu Terengganu yang hanya dituturkan di daerah Hulu Terengganu (Nasrun dan Collins 2017). Ajid telah menilai semula pengelompokan dialek Terengganu. Berdasarkan kajian lepas, Ismail (1973) meletakkan Terengganu dalam kelompok dialek Patani-Kelantan-Terengganu, Asmah (1976) kelompok 
Timur (Terengganu) dan Asmah (2008) dialek Terengganu sebagai kelompok KelantanPahang-Terengganu dengan kedudukan dialek Melayu Patani tidak jelas kedudukannya.

Ajid menjelaskan bahawa terdapat lima bukti linguistik yang mewajarkan ketiga-tiga dialek diletakkan di bawah satu tampuk kekeluargaan. Pertamanya, ketiga-tiga dialek ini mengalami proses pemonoftongan * aw $>$ a, *ay $>$ a pada akhir kata, 'hijau' [hijaw] menjadi [ija]. Kedua, ketiga-tiga dialek ini melemahkan konsonan plosif bersuara dalam rangkap konsonan homogen nasal plosif bersuara seperti 'rambut' [yambut] kepada [rambo?]. Ketiga perubahan $*_{\mathrm{i}}$ kepada /e/ dalam ketiga-tiga dialek Melayu tersebut. Keempat, ketiga-tiga dialek ini menggugurkan konsonan nasal dalam rangkap konsonan homogen nasal plosif tidak bersuara seperti 'pantai [pantaj] kepada [pata]. Kelima, ketiga-tiga dialek ini berkongsi sama proses pemanjangan konsonan pada awal kata - 'cari' [tfayi] menjadi [ty:ayi]. Kelima-lima ciri inovasi bersama yang terdapat dalam ketiga-tiga dialek ini dapat dijadikan bukti kukuh bahawa ketiga-tiga dialek ini tergolong ke dalam satu kelompok yang dapat dinamakan kelompok dialek Melayu Patani-Kelantan-Terengganu. Bukti linguistik ini juga disokong oleh persebaran geografi dan bukti sejarah. Dari segi geografi, ketiga-tiga dialek ini dituturkan di kawasan yang bertalian iaitu di sepanjang pantai timur Semenanjung Malaysia, bermula dari wilayah Patani di selatan Thailand menyusur ke Kelantan dan seterusnya menjalar ke sepanjang pantai Terengganu dan Pahang sehinggalah ke Mersing di Johor. Kawasan yang datar menjalar di sepanjang pantai ketiga-tiga negeri ini cukup kondusif dalam melahirkan satu kontinum dialek. Keadaan geografi sebegini memudahkan pergerakan atau pemindahan atau komunikasi antara penduduk di ketiga-tiga kawasan ini. Dari segi sejarah pula, ketigatiga kawasan ini pada suatu ketika dahulu terletak di bawah satu pemerintahan kerajaan Melayu yang besar berpusat di Patani dan dikenali sebagai kerajaan Melayu Patani Besar. Tambahan pula, penggunaan Bahasa Melayu dalam kalangan penutur masyarakat Islam di wilayah Pattani, Yala, Narathiwat, Songkla, Satun, dan wilayah-wilayah lain di sekitar Segenting Kra sudah menjangkau usia beribu-ribu tahun (Shahidi A.H.\&Mumad Che Laeh, 2020). Namun Ajid menegaskan kekerabatan antara dialek Patani dan Kelantan lebih erat berbanding dialek Terengganu. Sorotan dari Ajid sebenarnya telah mengemaskinikan lagi pencirian dialek Terengganu oleh Asmah (1985). Ajid juga telah mendakwa bahawa wujudnya kelompok dialek Melayu Patani-Kelantan-Terengganu yang berbeza dengan Asmah (2008).

Selari dengan era globalisasi, kajian dialek berdasarkan teknologi telah digiatkan misalnya oleh Chitsuko Fukushima (2016) dan Mitsuaki Endo (2018). Kini, Malaysia juga telah mengaplikasikan kajian dialek berdasarkan teknologi. Contohnya, kajian dialek Melayu di Perak (Nor Hashimah Jalaluddin et al., 2016), dialek Melayu di Kedah (Fazal Mohamed dan Amir Imran Jamil, 2019), dialek Satun di Langkawi (Nor Hashimah et al., 2017; Nor Hashimah et al., 2019). Kesemua kajian di atas telah menggunakan Sistem Maklumat Geografi atau GIS sebagai aplikasi dalam menghasilkan peta isoglos digital. Dengan kecanggihan teknologi ini, ketepatan kawasan dapat dibuktikan dengan adanya Global Positioning System (GPS).

Sehubungan dengan itu, artikel ini akan menyorot kajian terdahulu mengenai dialek Terengganu. Setiap huraian akan menyorot semula kajian yang terhasil 3 dekad dahulu iaitu;

(i) menilai semula pencirian fonologi dialek Terengganu,

(ii) menghasilkan peta isoglos dialek Terengganu yang dikatakan terbahagi kepada tiga kelompok, iaitu dialek pesisir pantai, dialek Hulu Terengganu dan dialek Kelantan

(iii) menambah baik huraian Ajid (2008) mengenai kelompok dialek Patani-KelantanTerengganu sehingga membentuk rantaian dialek di pantai timur. 
Kesemua sorotan ini akan menggunakan aplikasi GIS dan huraian geolinguistik. Apa yang pasti huraian mengenai dialek Terengganu akan ditambah baik sebagaimana pernah dilakukan oleh Suzuki (2012) pada dialek di Tibet dan Masaaki (2016) pada dialek di Vietnam.

\section{METODOLOGI}

Kajian lapangan merupakan satu proses pengumpulan data yang perlu dijalankan bagi mendapatkan data di kawasan yang dikaji. Kajian ini melibatkan seluruh negeri Terengganu. Melalui saringan dan Global Positioning System (GPS), sebanyak 64 buah kampung telah dipilih. GPS digunakan bagi membantu mengesan ketepatan titik kampung yang terpilih dan pada masa yang sama untuk memastikan jarak antara titik kampung itu munasabah. Saringan di sini bermaksud memilih titik kampung yang boleh memberikan maklumat yang tepat mengenai dialek Terengganu. Maka kawasan perumahan baharu, rancangan FELDA, dan kampung yang didiami oleh orang luar Terengganu akan digugurkan. Dalam beberapa kes, data dikumpulkan hanya beberapa lokasi dan diwakili oleh titik yang dianggap mewakili keseluruhan wilayah pentadbiran unit selaras dengan pandangan Sibler et al. (2012).

Pemilihan responden terdiri daripada tiga kategori iaitu warga tua (56 tahun ke atas), dewasa (26 tahun hingga 55 tahun) dan remaja (15 tahun sehingga 25 tahun) dilakukan secara rawak. Seramai lima ratus orang responden telah dipilih dengan pecahan seimbang iaitu 35\% golongan tua, 30\% dewasa dan 35\% remaja. Tiga kelompok ini dikategorikan kepada warga tua, dewasa dan remaja kerana julat umur yang sesuai dan mereka masih menggunakan dialek tempatan. Pembahagian ini penting kerana dapat melihat pola penggunaan dialek Melayu antara generasi (Nor Hashimah Jalaluddin et al., 2019). Pengumpulan data melibatkan tiga bahagian, iaitu pertama biodata responden, kedua maklumat topografi kawasan yang berada di sekitar kawasan kampung, dan ketiga menemu bual mengarah kepada penyebutan leksikal.

Dalam proses kajian lapangan, langkah temu bual turut digunakan bagi memastikan data yang dikutip oleh pengkaji lebih lengkap dan membantu memberi maklumat tambahan kepada soal selidik. Temu bual dijalankan melalui pertanyaan leksikal demi leksikal kepada penutur dialek Terengganu. Pemilihan perkataan untuk dianalisis berdasarkan kata asas selari dengan senarai Swadesh (Nor Hashimah et al., 2019). Leksikal ini adalah leksikal harian yang dipakai secara produktif oleh masyarakat Terengganu. Sejumlah 40 leksikal dipilih dan dikategorikan mengikut domain seperti flora dan fauna, kata kerja, kata adjektif, kata ganti nama, dan kata panggilan kekeluargaan yang mencirikan dialek Terengganu. Sebelum data dianalisis, data tersebut perlu ditranskripsikan menggunakan International Phonetics Alphabets (IPA) bagi mendapatkan representasi sebutan dengan baik dan tepat. Kesemua responden yang dipilih merupakan penutur natif dialek Terengganu. Penduduk asal kampung menjadi responden utama kepada pengkaji bagi mendapatkan varian leksikal yang bakal dikaji.

Dalam penganalisisan data, perisian pemetaan Geographic Information System (GIS) telah digunakan. Sebelum diaplikasikan dalam ArcGis, pembersihan data akan dilakukan bagi meneliti semula data yang telah dikumpulkan. Pengkaji akan memasukkan data yang bersih dalam paparan Microsoft Excel yang memuat jadual keseluruhan varian leksikal berdasarkan titik-titik kampung yang telah dikenal pasti. Proses penganalisisan data akan dilaksanakan dengan memasukkan jadual atribut perisian ArcGIS dan diproses membentuk peta variasi leksikal. Peta choropleth berfungsi sebagai peta yang dapat memaparkan pola atau taburan leksikal berdasarkan kekerapan leksikal yang digunakan. Gambar di bawah menunjukkan sebahagian daripada data yang dimasukkan dalam Microsoft Excel sebelum diproses dalam ArcGis. 


\begin{tabular}{|c|c|c|c|c|c|c|c|c|c|c|c|c|c|c|c|c|c|c|c|c|c|}
\hline 1 & DATA DIALEK TERENGGANU & & & & & & & & & & & & & & & & & & & & \\
\hline 2 & LEKSIKAL & Air & & Ayam & & & & & & & & & & & & & & & & & ling \\
\hline Bil. & DARERAH/MUKIM & & aian & aiam & Ois & nlak an & nckon & nolck & |lsm & lot? & trana? & tran? & tho? & Jeng & neton & plston & bahan & bindah & kslon & makon & nlckon k \\
\hline 4 & KAMPUNG & . & | de & 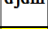 & aje & | & pEST] & pDIEA Ji & |reps & 1000 & gopdi & gopN & | & $10 \mathrm{pu}$ & petoi] & | & ouray & 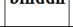 & ลE(J) & | & PIEATIJ \\
\hline 5 & KEMAMAN & & & & & & & & & & & & & & & & & & & & \\
\hline 94 & Kg Chabang & ae & ajal] & & & & & & lep & & & & & & & & & & & & \\
\hline 105 & Kg Cagar & ae & ajal) & & & & & & lepo & & & & & & & & & & & & \\
\hline 116 & Kg Perasing Jaya & ae & ajal] & ajam & & & pek Ji & & leps & loto & & & & & & & & & & & \\
\hline 127 & Kg Pasir Gajah & ae & ajal] & & & & & palekır] & $1 \varepsilon p$ & & & tapo? & & & & & & & & & \\
\hline 138 & Kg Dadong & ae & aja1] & & & & & palekor] & leps & & & & & & & & & & & & \\
\hline 149 & Kg Laut & ae & ajal] & & & & & & & & & & toho? & lepa & & & & & & & \\
\hline 1510 & Padang Kubu & ae & ajau & & & & pekjol & & leps & & & & & & pet51] & pletıy & \begin{tabular}{|l|} 
bahal \\
\end{tabular} & & & & \\
\hline 16 & DUNGUN & & & & & & & & & & & & & & & & & & & & \\
\hline 1711 & Kg Durian Mas & ae & ajal] & & & & pekon & & & & & & & & peton] & & & & & & \\
\hline${ }_{18}^{18} 12$ & Kg Syukur & ae & ajal] & & & & pekon] & & & & & & & & & & & bindah & & & \\
\hline 1913 & Kg Kuala Jengai & ae & ajal] & & & & 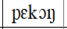 & & leps & & & & & & & & & & & & \\
\hline 2014 & Kg Talam & ae & ajal] & & & & & & leps & & & & & & & & & & & & \\
\hline 2115 & Kg Panchur & ae & aja1) & & & & pekon & & & & & & & & & & & & kelon] & pekor] & \\
\hline 2216 & Kg Tebing Tembah & ae & ajal] & & & & pekor & & leps & & & & & & peto1] & pleton & & & & & plekoy \\
\hline${ }_{23} 17$ & Kg Durian Mentangau & ae & ajal] & & $\mathrm{aj \varepsilon}$ & & pekon & & lepo & & & & & & & & & & & & pleko1] \\
\hline 24 & Kg Rantau Abang & ae & ajal] & & & & pek Ji] & & & & & & & & & pleton & & & kelol] & & plekon \\
\hline $25 \quad 19$ & Kg Nibung & ae & ajal] & & & & pekon & & $1 \varepsilon p$ & & & & & & & & & & & pak 01 & pleko1 \\
\hline 2620 & Kg Payung Kemudi & ae & ajal] & & & & pekon & & & & & & & & & & & & kelon] & pak 01$]$ & plekə1) \\
\hline 2765 & Kg Pasir Raja (FW2) & ae & ajal] & ajam & & & & & $1 \varepsilon p$ & & tapo? & & & & & & & bindah & & & plekoy \\
\hline-7. & MARANG & & & & & & & & & & & & & & & & & & & & \\
\hline 2021 & Kg Jambu Bongkok & ae & aja1) & & & & pek on] & & lepo & & & & & & & & & & & & plekon \\
\hline 3022 & Kg Gong Balai & ae & ajal] & & & & pekon & & leps & & & & & & & & & & & & \\
\hline 3123 & Kg Pantai Merchang & ae & ajal] & & & & pekor) & & lepo & & & & & & & & & & & & \\
\hline$3 2 \longdiv { 2 4 }$ & Kg Tok Do & ae & $\mid$ ajal $\mid$ & & & & & & | 1 lep & & & & & & & & & & & & plekoy \\
\hline$k$ & Sheet1 & + & & & & & & & & & & & 4 & & & & & & & & , \\
\hline
\end{tabular}

RAJAH 1. Contoh data yang dimasukkan dalam Microsoft Excel

Dari perbezaan varian yang ditemui, pengkaji akan menghasilkan plot yang sesuai dengan input data. Dua jenis peta dialek akan dihasilkan, iaitu peta isoglos bagi penentuan sempadan dialek dan sub dialek dan peta choropleth yang menandakan dengan tepat taburan varian yang dikutip di lapangan. Akhirnya huraian peta ini akan dilengkapkan dengan maklumat bukan linguistik bagi menjelaskan dengan terperinci mengapa pola taburan varian adalah sedemikian rupa. Maklumat topografi, sejarah dan sosio-budaya akan menjadi faktor peneguh pada huraian ini.

\section{PERBINCANGAN}

Terdapat tiga aspek yang akan dikupaskan dalam bahagian ini. Pertamanya, ialah sorotan pencirian dialek Terengganu yang pernah dibincangkan oleh Asmah (1985), kedua isoglos peta dialek Terengganu dengan dialek yang bersempadan berdasarkan kenyataan Asmah dan Collins (dalam Nasrun dan Collins 2017). Manakala yang ketiga adalah kedominanan dialek Terengganu sepanjang pantai timur yang diutarakan oleh Ajid (2008). Kajian ini akan menghuraikan tiga aspek dialek Terengganu ini berasaskan geolinguistik dengan huraian tambahan faktor bukan linguistik dan akhirnya menghasilkan deskripsi baharu tentang dialek Terengganu.

\section{ASPEK FONOLOGI DIALEK TERENGGANU}

Terengganu merupakan negeri Pantai Timur yang mempunyai keunikan dalam dialeknya. Asmah Hj Omar (1985) telah menyenaraikan ciri dialek Terengganu dengan membandingkan ciri-ciri ini mengikut sub dialek. Kemudian ciri ini dikemaskan semula oleh Ajid (2008). Bezanya, kajian Ajid yang ringkas hanya memberikan ciri fonologi yang kemas tetapi terhad dari segi contohnya. Manakala, Collins telah memfokuskan dialek Terengganu di kawasan Hulu Terengganu sahaja. Sebagai rumusan daripada kajian lepas dan tambahan dari input data yang baharu yang dikutip pada Januari 2020, pengkaji telah menyenaraikan lima ciri fonologi dialek Terengganu seperti di bawah: 
i) perubahan velar nasal di akhir kata

ii) homoganik nasal digugurkan apabila bertemu bunyi letupan tidak bersuara

iii) perubahan frikatif alveolar $/ \mathrm{s} /$ kepada $/ \mathrm{h} /$

iv) likuida /1/ dan /r/ digugurkan di akhir kata dan perubahan diftong kepada monoftong.

Sebagai penambahbaikan daripada pencirian Asmah (1985) dan Ajid (2008), kesemua dialek ini akan melalui rumus fonologi bagi membezakannya dari sebutan standard (Zaharani Ahmad, 1993). Berikut ditunjukkan bagaimana proses perubahan fonologi dari bahasa standard ke dialek Terengganu berlaku.

i. Penggantian nasal (N) yang bertukar kepada nasal /y/, $N$ mewakili bunyi nasal $/ \mathrm{m}, \mathrm{n} /$. Perubahan nasal dari bunyi dua bibir $/ \mathrm{m} /$ atau alveolar $/ \mathrm{n} /$ bertukar ke bunyi nasal lelangit lembut $/ \mathrm{y} /$. Simbol N mewakili konsonan $/ \mathrm{m} /$ dan $/ \mathrm{n} /$ dalam rumus berikut:

$$
\mathrm{N} \rightarrow \mathrm{y} / \ldots
$$

Dalam fonologi, ini adalah proses perubahan bunyi kerana bunyi ini dalam kelompok yang sama. Yang berlaku adalah perubahan titik artikulasi. Jadi semua leksikal yang berakhir dengan nasal /m,n/ akan mengalami proses penggantian ini. Contohnya;

JADUAL 3. Senarai leksikal Velar Nasal

\begin{tabular}{|c|c|}
\hline \multicolumn{2}{|c|}{ Velar Nasal Di Akhir Kata } \\
\hline Bahasa Melayu Standard & Dialek Terengganu \\
\hline [ajam] & [ajan] \\
\hline [ikan] & [ikay] \\
\hline [duyijan] & [duyijay] \\
\hline [yambutan] & [yambutay] \\
\hline [masam] & [masay] \\
\hline [pisay] & [pisay] \\
\hline [kəbon] & [kəboy] \\
\hline [pəlam] & [pəlay] \\
\hline & [məmpəlay] \\
\hline
\end{tabular}

Daripada 40 leksikal yang dikutip di lapangan, terdapat lapan leksikal yang membuktikan kewujudan perubahan nasal ini. Ciri ini memang telah dipersetujui oleh semua pengkaji dialek Terengganu. Peta di bawah dapat mengesahkan kehadiran ketiga-tiga varian yang dinyatakan di atas. 


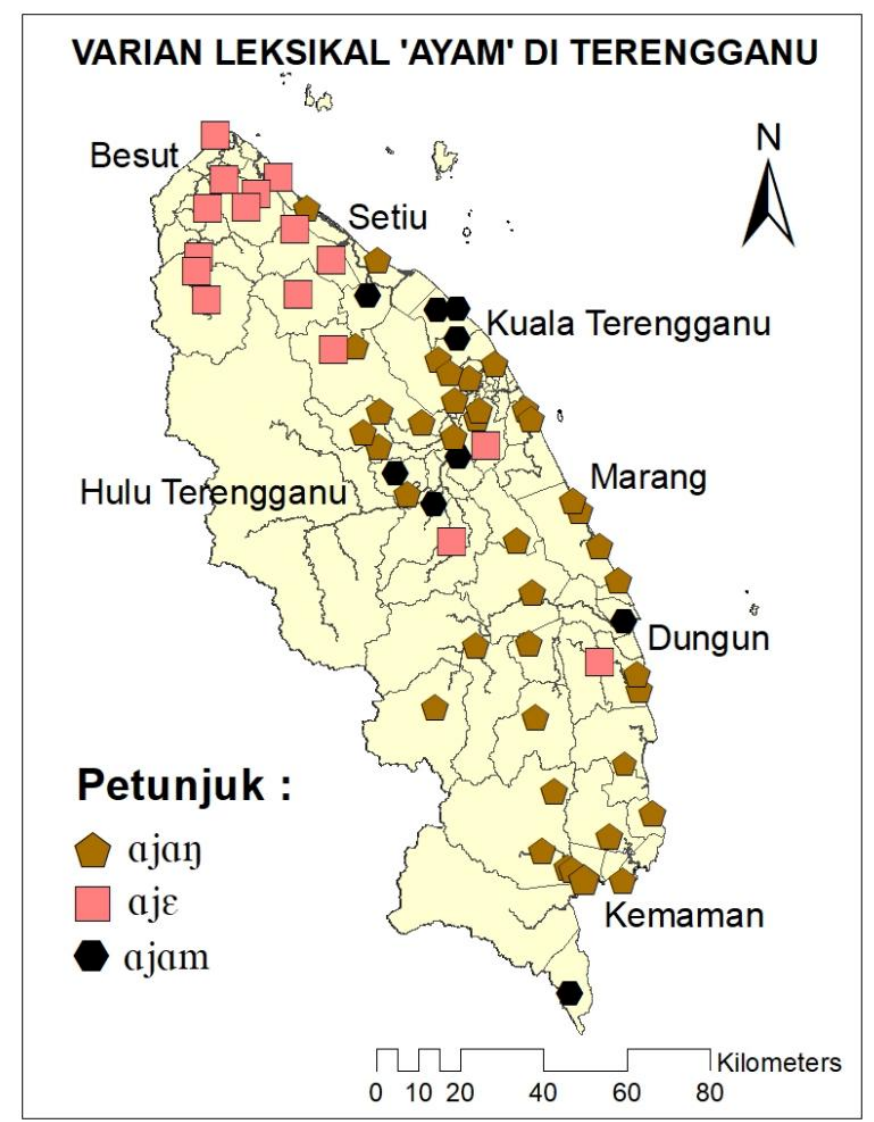

PETA 2. Taburan Leksikal 'ayam'

Peta 2 memaparkan leksikal 'ayam' disebut sebagai [ajan], [ajam] dan [aje] mengikut sub-dialek yang ada. Berdasarkan Collins (1983) dan Ismail Hussein (1973), leksikal 'ayam' disebut sebagai [ajay] di Terengganu dan telah diperkukuhkan oleh Asmah Hj. Omar (1985). Dalam peta 2, pengkaji menemukan 3 varian iaitu bunyi [ajay] diwakili simbol $\square$ ternyata lebih dominan berbanding [ajam] diwakili simbol dan [aje] diwakili simbol $\square$. [aje] digunakan di kawasan Besut dan Setiu yang dikatakan dipengaruhi oleh dialek Kelantan. Terdapat titik sporadik tetapi tidak signifikan bagi bunyi [aje] di bahagianbahagian lain negeri Terengganu seperti di Hulu Terengganu, Dungun, dan Marang. [ajam] diwakili simbol juga ditemui di Terengganu. Ini adalah sebutan baku bagi leksikal 'ayam'. Hal ini boleh terjadi kerana adanya orang luar Terengganu yang berkhidmat di situ dan kekal dengan sebutan baku. Walau bagaimanapun bunyi [ajay] tetap menonjol.

ii. Setiap konsonan nasal yang hadir bersama dengan bunyi letupan tidak bersuara akan digugurkan. $\mathrm{N}$ iaitu nasal mewakili bunyi $/ \mathrm{m} /, \mathrm{n} /$, dan $/ \mathrm{y} /$ akan digugurkan apabila hadir bersama $\mathrm{P}$ iaitu plosif mewakili /p/, /t/ dan /k/. Hal ini dapat dirumuskan seperti berikut:

$$
\mathrm{N} \rightarrow \varnothing / \ldots \mathrm{P}[- \text { suara }]
$$

\section{Bahasa Melayu Standard} [bantal]
Dialek Terengganu

[bata] 


\begin{tabular}{cc}
\hline $\begin{array}{c}\text { Homoganik Nasal Digugurkan } \\
\text { Bahasa Melayu Standard }\end{array}$ & $\begin{array}{c}\text { Bertemu Letupan Tidak Bersuara } \\
\text { Dialek Terengganu }\end{array}$ \\
\hline$[$ bantal $]$ & {$[$ bata $]$} \\
{$[$ pantaj] } & {$[$ pata $]$} \\
{$[$ tumpol $]$} & {$[$ tupo $]$} \\
{$[$ manko? $]$} & {$[$ mako? $]$} \\
\hline
\end{tabular}

Asmah (1985) menamakan proses ini sebagai rangkap konsonan. Proses pengguguran bunyi nasal berlaku secara konsisten. Cuma artikel ini menamakan proses in sebagai pengguguran homoganik nasal mengikut rumus fonologi yang disarankan oleh Zaharani (1993). Asmah (1985) memberikan contoh, 'tangkul, tempat, cincang dan pintal' dan kajian ini menambah empat lagi data baharu. Peta 3 dapat menghuraikan taburan pengguguran homoganik nasal.

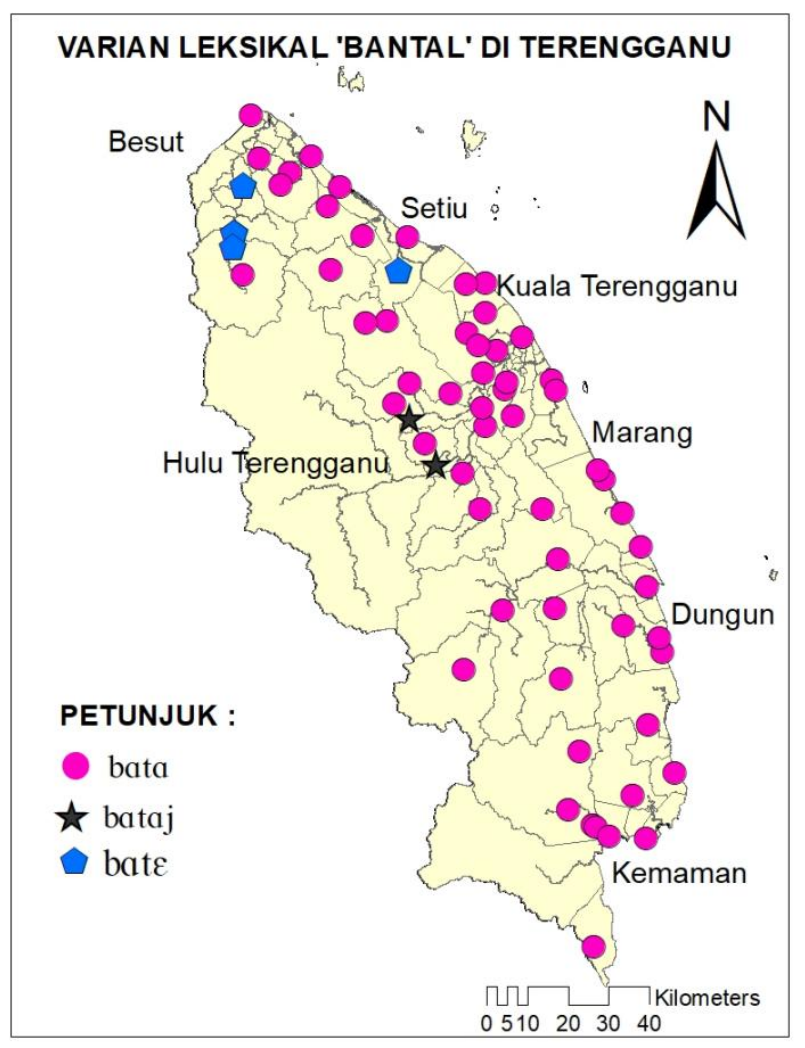

PETA 3. Taburan Leksikal 'bantal'

Peta 3 menunjukkan leksikal [bata] diwakili simbolOdan kedominan sebutannya menguasai keseluruhan Terengganu. Namun begitu, ada perbezaan sebutan di Besut dan Setiu yang menggunakan [bate] diwakili simbol . Pengaruh dialek Kelantan telah dikenal pasti di Terengganu (Asmah, 1985; Ajid, 2008). Bunyi yang menarik perhatian pengkaji, varian [bataj] di Hulu Terengganu diwakili simbol $\downarrow$. Berdasarkan jadual $1 \mathrm{di}$ atas, Collins hanya menyenaraikan bunyi diftong bagi suku kata terbuka, iaitu vokal yang mengalami diftongisasi, namun kajian ini menemukan data likuida yang mengalami proses pengguguran diikuti dengan diftongisasi di Hulu Terengganu. Ini dianggap sebagai input baharu pada sub dialek Hulu Terengganu (lihat jadual 8). 
iii. Leksikal yang diakhiri dengan bunyi konsonan likuida /1/ dan getaran /r/ akan digugurkan. $\mathrm{L}$ mewakili /1/ dan /r/ dalam rumus berikut:

$$
\mathrm{L} \rightarrow \varnothing /
$$
\#

JADUAL 5. Senarai Leksikal Pengguguran Likuida

\begin{tabular}{cc}
\hline \multicolumn{2}{c}{ Likuida /// dan /r/ Digugurkan di Akhir Kata } \\
Bahasa Melayu Standard & Dialek Terengganu \\
\hline$[$ pukol] & {$[$ puko] } \\
{$[$ koto $]$} & {$[$ koto $]$} \\
{$[$ kapal $]$} & {$[$ kapa $]$} \\
{$[$ ulay $]$} & {$[\mathrm{ulo}]$} \\
\hline
\end{tabular}

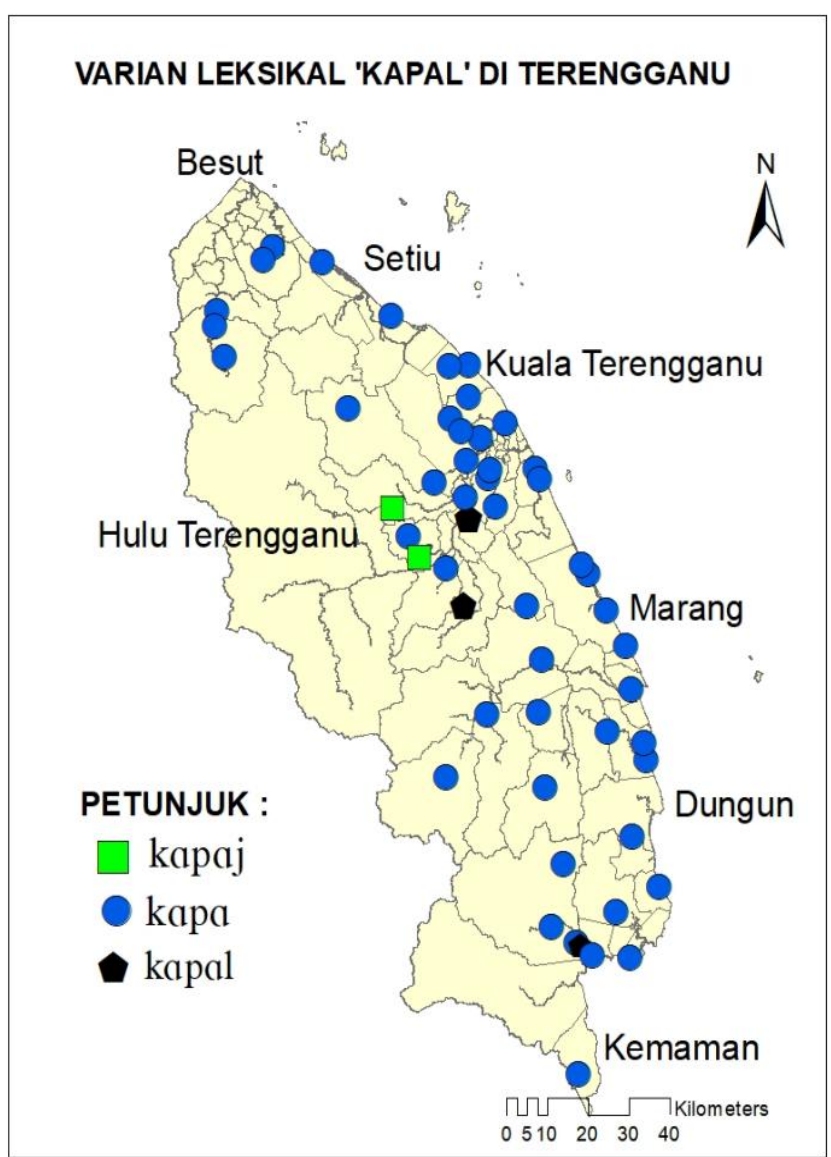

PETA 4. Taburan Leksikal 'kapal'

Asmah (1985) memberikan contoh leksikal, 'tabir, fikir, liar tidur, liur, telur dan akar' bagi membuktikan pengguguran bunyi /r/ di akhir kata. Pengkaji telah memetakan taburan /kapal/ seperti dalam peta di atas. Peta 4 menunjukkan secara keseluruhan [kapa] yang diwakili simbolOdigunakan di setiap daerah. Sebutan [kapal] yang menggunakan lambang $\triangle$ menjadi kebiasaan penutur bahasa Melayu standard menggunakannya. Walau bagaimanapun, di kawasan Hulu Terengganu terdapat segelintir penduduk menyebut [kapaj] yang diwakili simbol $\square$ dalam peta. 
iv. Penggantian frikatif alveolar $/ \mathrm{s} /$ kepada $/ \mathrm{h} / \mathrm{di}$ akhir kata di daerah artikulasi yang sama berlaku dalam dialek Terengganu. Hal ini dirumuskan seperti berikut:

$$
\mathrm{s} \rightarrow \mathrm{h} /
$$

JADUAL 6. Penggantian Frikatif

\begin{tabular}{cc}
\hline \multicolumn{2}{c}{ Frikatif Alveolar /s/ kepada $/ \mathbf{h} /$} \\
Bahasa Melayu Standard & Dialek Terengganu \\
\hline$[$ tikus] & {$[$ tikuh] } \\
{$[$ kupas $]$} & {$[$ kupah] } \\
{$[$ malas] } & {$[$ malah] } \\
{$[$ kipas $]$} & {$[$ kipah] } \\
{$[$ manis $]$} & {$[$ maneh $]$} \\
[pedas] & {$[$ pədah] } \\
\hline
\end{tabular}

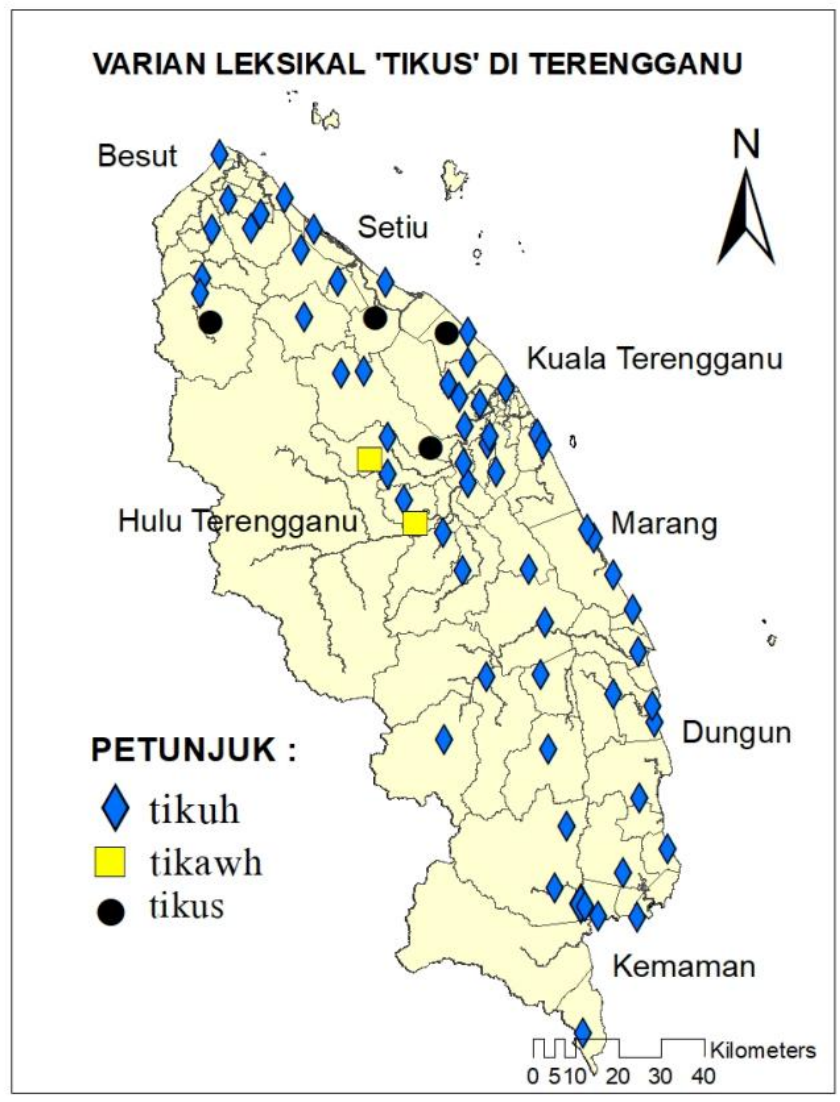

PETA 5. Taburan Leksikal 'tikus'

Secara dominannya, [tikuh] diwakili simbol $\vee$ digunakan dalam sebutan. Bahasa Melayu Standard bagi [tikus] dengan simbol juga digunakan namun hanya di segelintir kawasan sahaja. Menariknya, simbol $\square$ yang melambangkan bunyi [tikawh] terdapat di Hulu Terengganu. Fenomena fonologi iaitu penokokan geseran pada akhir kata atau diftongisasi berlaku sebagaimana disebut oleh Collins (1983). 
v. Diftong melalui proses monoftong . Diftong adalah dua vokal yang hadir serentak dengan satu puncak kelantangan seperti 'ai'/aj/, 'au'/aw/, 'oi' /oj/. Dari segi fonologi berlaku pengguguran geluncuran bagi bunyi /w,y/ yang diwakili oleh lambang G. Rumusannya adalah seperti berikut:

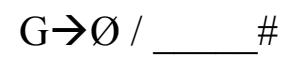

JADUAL 7. Monoftongisasi

\begin{tabular}{cc}
\hline \multicolumn{2}{c}{ Perubahan Diftong kepada Monoftong } \\
Bahasa Melayu Standard & Dialek Terengganu \\
\hline$[$ katfaw $]$ & {$[$ kutfa $]$} \\
{$[$ səyaj $]$} & {$[$ səya $]$} \\
{$[$ pantaj $]$} & {$[$ pata $]$} \\
\hline
\end{tabular}

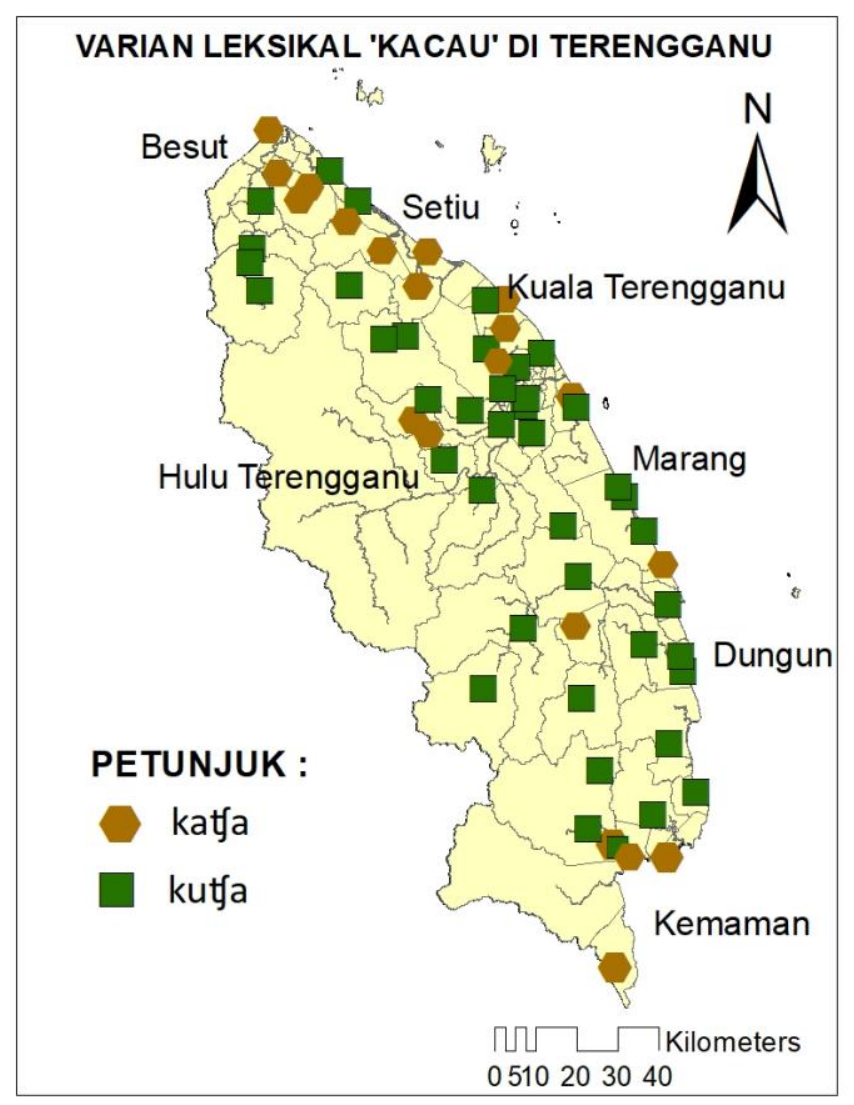

PETA 6. Taburan Leksikal 'kacau'

Lakaran peta 6 memaparkan varian leksikal 'kacau' yang mempunyai dua varian iaitu [katfa] diwakili simbol dan [kutfa] diwakili simbol $\square$. Leksikal 'kacau' dijadikan sebagai contoh yang menepati aspek pencirian fonologi iaitu perubahan diftong ke monoftong atau proses monoftongisasi di akhir kata.

Selain lima ciri fonologi di atas, pengkaji juga akan mengulas mengenai kehadiran bunyi diftong yang dianjurkan oleh Collins (1983) di Hulu Terengganu. Dalam jadual 1 di atas, Collins telah menyenaraikan sebanyak 12 leksikal yang mempunyai bunyi diftong. Dalam kajian ini, sebanyak 15 leksikal tambahan dikemukakan sebagai pengukuhan. 
JADUAL 8. Sub-Dialek Hulu Terengganu

\begin{tabular}{|c|c|c|c|c|c|c|}
\hline $\begin{array}{l}\text { Bahasa } \\
\text { Melayu }\end{array}$ & $\begin{array}{c}\text { Kg. } \\
\text { Basung }\end{array}$ & $\begin{array}{c}\text { Kg. } \\
\text { Baong }\end{array}$ & $\begin{array}{l}\text { Kg. } \\
\text { Teris }\end{array}$ & $\begin{array}{l}\text { Kg. } \\
\text { Gaong }\end{array}$ & Kg. Jenagor & $\begin{array}{l}\text { Kg. Kuala } \\
\text { Pueh }\end{array}$ \\
\hline tikus & tikawh & tikuh & tikuh & tikawh & tikawh & tikuh \\
\hline lembu & ləmbaw & lombaw & ləmbaw & ləmbuw? & ləmbəw & ləmbəw \\
\hline kopi & kupaj & kupi & kupaj & kupaj & kupej & kupej \\
\hline suami & lakaj & laki & lakaj & laki ${ }^{\mathrm{i}}$ ? & lakej & laki \\
\hline isteri & $\operatorname{bina}^{j} y$ & bini & binaj & binin & binej & binej \\
\hline baling & bala $^{\mathbf{j}} \mathbf{y}$ & kaloy & kalown $^{w}$ & kalown $^{w}$ & kalon & kaloy \\
\hline cubit & $\mathrm{t} f \partial \mathrm{ka}^{\mathrm{j}}$ ? & tJoki? & toki? & təaki? & tyubaj? & tyaki? \\
\hline gemuk & gəmaw? & gəmo? & gəmaw? & gəmaw? & gəmaw? & gəmaw? \\
\hline saya & akaw & $\mathrm{kama}^{\mathrm{j}} \mathrm{y}$ & akaw & $\mathrm{kama}^{\mathrm{j}} \mathrm{y}$ & $\mathrm{kama}^{\mathrm{j}} \mathbf{y}$ & akaw \\
\hline pantai & patta & patta & patta & pata & patta & pata \\
\hline pahit & paha $^{j_{1}}$ & pahe? & pahe? & pahe? & pahe? & pahe? \\
\hline manis & $\operatorname{mana}^{\mathrm{j} h}$ & maneh & maneh & maneh & maneh & maneh \\
\hline bantal & bata & bataj & bata & bata & bataj & bata \\
\hline kapal & kapa & kapaj & kapa & kapa & kapaj & kapa \\
\hline pedas & pədah & pədah & pədah & pədah & pəda $a^{j} h$ & pədah \\
\hline
\end{tabular}

Rumusan dari sorotan yang dilakukan dari aspek fonologi adalah seperti berikut:

i. transkripsi yang digunakan dalam kajian ini lebih teratur mengikut International Phonetics Alphabet (IPA) berbanding transkripsi Asmah (1985) yang lebih sukar untuk difahami. Memandangkan penulisan Asmah terhasil pada tahun 80an dan penggunaan lambang fonetik belum meluas di Malaysia, maka Asmah telah menggunakan lambang sendiri bagi menunjukkan adanya perubahan bunyi. Contohnya, Asmah menggunakan /e/ untuk /ə/, /ê/ untuk /e/, /ô/ untuk /o/ bagi bunyi vokal. Asmah turut menggunakan lambang /q, ng, j, r/ yang sepatutnya lambing / $, \mathrm{y}, \mathrm{d}_{3}, \mathrm{\gamma} /$. Penggunaan lambang fonetik yang tepat dalam kajian ini telah menambah baik transkripsi yang lama.

ii. Penggunaan rumus fonologi yang lebih teratur berbanding dengan huraian tanpa rumus yang agak sukar untuk difahami. Contohnya, bagi ciri penggantian nasal $\mathrm{N} \rightarrow \mathrm{y} / \ldots$, Asmah telah mendeskripsikan seperti ini:

"hanya ng yang dapat menempati kesemua lingkungan yang diperkatakan. Konsonan-konsonan
nasal yang lainnya hanya dapat menempati lingkungan pravokal dan antara vokal" (Asmah 1985, hlm. 285).

Begitu juga dengan penggantian frikatif, homoganik nasal dan plosif tidak bersuara, monoftongisasi dan pengguguran likuida. Ternyata penggunaan rumus fonologi lebih mudah untuk difahami berbanding deskripsi yang diberikan oleh Asmah (1985).

iii. Selain ciri fonologi yang diberikan oleh Asmah (1985), senarai diftong Collins (1983) juga telah ditambah baik. Collins memfokuskan kepada suku kata terbuka. Sedangkan dalam kajian ini ditemui banyak suka kata tertutup juga mengalami proses diftongisasi seperti 'tikus, baling, cubit, gemuk, pahit, manis dan bantal. Contohnya, /tikawh/, /bala ${ }^{\mathrm{j}} \mathrm{y} /$,

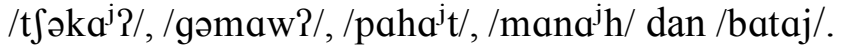


Dari sorotan ini, pengkaji telah dapat melengkapkan lagi senarai kata berdiftong yang menggunakan suku kata tertutup. Ini menjadikan senarai kata berdiftong lebih lengkap. Selain itu, kajian juga mendapati bunyi diftong telah menjadi lebih mudah dengan pengguguran banyak fonetik sekunder seperti yang disenaraikan oleh Collins (1983). Ini bertepatan dengan kajian Nasrun dan Collins (2017) yang mendapati banyak berlaku perubahan ciri diftong dalam kalangan penutur Hulu Terengganu. Kajian ini dapat menambah kata panggilan $/ \mathrm{kama}^{\mathrm{j}} \mathrm{y} /$ selain daripada /akaw/ dan sekali gus mengesahkannya berserta bukti yang jelas, yang tidak dilakukan oleh Nasrun dan Collins (2017) dengan nyata. Kini hanya ditemui bunyi-bunyi berdiftong yang lebih mudah bunyinya sebagaimana contoh di bawah:

JADUAL 9. Penemuan diftong nyata dan baharu

\begin{tabular}{|c|c|c|c|c|c|c|}
\hline \multicolumn{7}{|c|}{ Leksikal 'aku' } \\
\hline $\begin{array}{l}\text { Nasrun dan Collins } \\
\text { (2017) }\end{array}$ & aktw & akuw $^{\text {h }}$ & $\mathrm{aku}^{\mathrm{n}} \mathrm{w}$ & aka’w & akəw? & akəw $^{k}$ \\
\hline $\begin{array}{c}\text { FRGS } / 1 / 2019 / \mathrm{SSI} 01 / \mathrm{U} \\
\mathrm{KM} / 01 / 1\end{array}$ & akaw & $\operatorname{kama}^{\mathrm{j}} \eta$ & akaw & $\operatorname{kama}^{\mathrm{j}} \mathrm{\eta}$ & $\mathrm{kama}^{\mathrm{j}} \mathrm{\eta}$ & akaw \\
\hline
\end{tabular}

Pertambahan yang nyata dan baharu adalah penghasilan peta isoglos dan choropleth yang mampu memplotkan taburan ciri fonologi yang jelas dan pada masa yang sama menunjukkan jumlah varian yang ada bagi setiap leksikal. Kesemua lima peta di atas membuktikan kehadiran varian yang berbeza sama ada varian pesisir Terengganu, Hulu Terengganu dan varian dialek Kelantan. Pemerian peta yang jelas adalah satu inovasi pada kajian dialek Terengganu itu sendiri.

\section{GARIS ISOGLOS DIALEK TERENGGANU DAN DIALEK KELANTAN}

Mengikut Nasrun Alias dan James T. Collins (2017), pada umumnya dialek di Terengganu boleh dibahagi kepada tiga kelompok, iaitu Terengganu Pantai, Kelantan, dan Hulu Terengganu. Dialek Terengganu Pantai digunakan sebagai alat komunikasi di semua daerah pesisir pantai, iaitu dari Kemaman sehinggalah sebahagian daerah Setiu. Seterusnya, dialek Kelantan dituturkan di sebahagian lagi daerah Setiu sehinggalah ke Besut. Dialek Hulu Terengganu hanya dituturkan di daerah Hulu Terengganu. Oleh itu, sub dialek Melayu Terengganu itu sendiri dapat dikenal pasti secara am.

Menurut Asmah Hj Omar (1985) dan James T. Collins (1996) sebahagian Setiu dan Besut menggunakan dialek Kelantan walaupun di dalam naungan negeri Terengganu. Ajid Che Kob (2008) telah memberikan penyataan bahawa dialek Terengganu merupakan subkelompok tersendiri dan terpisah daripada subkelompok dialek Melayu Kelantan dan Patani akibat jarak geografi. Bagi menjelaskan objektif kedua deskripsi dialek Terengganu, kajian ini menghuraikan titik pemisah antara dialek Kelantan dan dialek Terengganu. Semasa kajian dilakukan, daerah Setiu dibahagikan kepada dua bahagian iaitu Setiu Laut dan Setiu Darat. Daripada data yang dikutip, terbukti Setiu Darat menjadi garis sempadan isoglos antara dua dialek iaitu dialek Terengganu dan dialek Kelantan. Besut merupakan salah satu daerah di Terengganu, namun dialek yang digunakan dominannya adalah dialek Kelantan. Salah satu cerita sejarah mengenai asal nama Besut kononnya berpunca dari zaman dahulu di mana dikatakan Besut merupakan salah sebuah kawasan di bawah kuasa Kerajaan Siam. Mengikut ceritanya, nama Besut timbul dari perkataan 'BE' yang dalam bahasa Siam bermakna daerah manakala 'SUT' menggambarkan satu tempat atau kawasan yang paling jauh atau penghujung. Ini mungkin betul berdasarkan faktor betapa jauhnya Bangkok yang merupakan Pusat Pentadbiran Siam dengan daerah ini (PTDB, 2012). Kesan daripada faktor sejarah ini, dialek Kelantan di Besut mendominasi penduduknya walaupun kini di dalam naungan Terengganu. 
Jadual 10 di bawah menunjukkan leksikal-leksikal yang mengalami perubahan dialek Terengganu kepada dialek Kelantan.

JADUAL 10. Perubahan leksikal daripada dialek Terengganu kepada dialek Kelantan

\begin{tabular}{|c|c|c|c|}
\hline Leksikal & \begin{tabular}{l}
\multicolumn{1}{c}{ Setiu Laut } \\
Kg Pangkalan Gelap, \\
Kg Banting Lintang, \\
Kg Bari Besar, Kg \\
Kubang Puyu
\end{tabular} & \begin{tabular}{l}
\multicolumn{1}{c}{ Setiu Darat } \\
Kg Banggol, Kg \\
Bahagia, Kg Sungai \\
Pinang, Kg Langkap \\
Baru, Kg Payong, Kg \\
Padang
\end{tabular} & \begin{tabular}{l}
\multicolumn{1}{c}{ Besut } \\
Kg Pak Wong, Kg \\
Tok Saboh, Kg \\
Tempinis, Kg Gong \\
Penaga, Kg Darau, \\
Kg Batu 13, Kg La, \\
Kg Pok Sik \\
\end{tabular} \\
\hline Ayam & ajay & aje & aje \\
\hline Dia & dijə & dijo & dijo \\
\hline Kamu & mun & dem & dem \\
\hline Saya & $\begin{array}{l}\text { kitə } \\
\text { ambə }\end{array}$ & $\begin{array}{l}\text { kawe } \\
\text { ambo }\end{array}$ & $\begin{array}{l}\text { kawe } \\
\text { ambo }\end{array}$ \\
\hline Durian & duyijan & duyije & duyije \\
\hline Ibu & mo? & $m \varepsilon ?$ & $m \varepsilon ?$ \\
\hline Ikan & ikay & $\mathrm{ik} \varepsilon$ & $\mathrm{ik \varepsilon}$ \\
\hline Kotor & koto & təma & təma \\
\hline Malas & malah & maleh & maleh \\
\hline Pelam & pəlay & paoh & paoh \\
\hline Masam & masay & mase & $\operatorname{mas} \varepsilon$ \\
\hline Pisang & pisay & pise & pise \\
\hline Pukul & kato? & $\operatorname{god} \varepsilon$ & $\operatorname{god} \varepsilon$ \\
\hline Rambutan & yambutay & morte & mopte \\
\hline suka & sukə & sukっ & suko \\
\hline
\end{tabular}

Dari senarai leksikal di atas, sahlah bahawa daerah Setiu terbahagi dua, iaitu Setiu Laut lebih kepada penggunaan dialek pesisir Terengganu sementara Setiu Darat lebih kepada dialek Kelantan. Hampir keseluruhan Besut menggunakan dialek Kelantan. Input baharu kesan dari sorotan yang dilakukan ialah telah ditemui titik isoglos yang tepat menggantikan pendapat Asmah Hj Omar (1985) dan James T. Collins (1996) dalam persempadanan dialek. Inovasi berasaskan GIS menunjukkan sempadan yang jelas yang tidak pernah dilakarkan sebelum ini. Kini kita dapat perhatikan garis pemisah yang jelas di antara kedua-dua dialek Terengganu dan Kelantan. Peta 7 di bawah jelas menunjukkan garis isoglos yang memisahkan ketiga-tiga subdialek, iaitu sub-dialek Pesisir Pantai, sub-dialek Hulu Terengganu dan dialek Kelantan. 


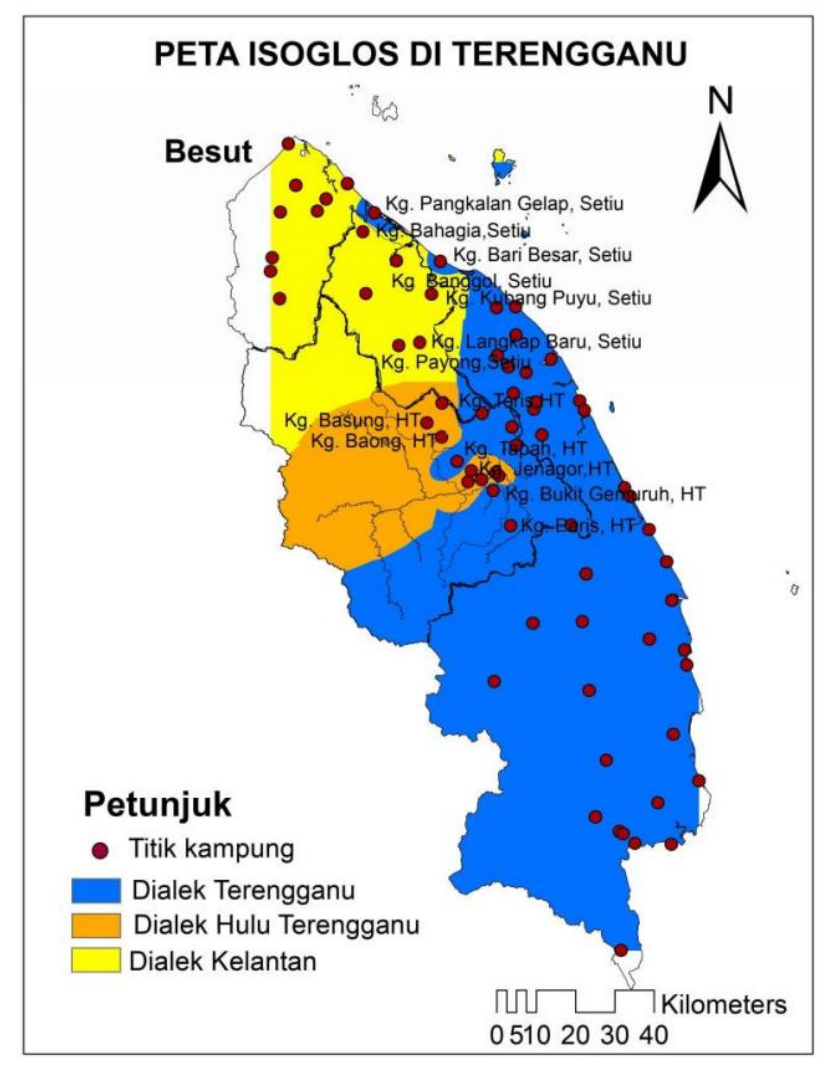

PETA 7. Peta sempadan dialek Terengganu dan dialek Kelantan

\section{KEDOMINANAN PENYEBARAN DIALEK TERENGGANU DI PANTAI TIMUR MALAYSIA}

Bahagian ini menjawab objektif ketiga pula. Salah satu dapatan yang menarik kesan daripada sorotan ini ialah terhasilnya peta kedominanan dialek Terengganu di sepanjang pantai timur. Ajid (2008) ada menyatakan dengan ringkas perihal isoglos dialek pantai timur. Ajid mengelompokkan Patani, Kelantan dan Terengganu sebagai dialek pantai timur. Kedominan diukur daripada kewujudan varian di sepanjang pantai timur Semenanjung Malaysia. Nor Hashimah et.al (2021) telah membuktikan memang wujudnya dialek Terengganu di Johor iaitu di Mersing dan Kota Tinggi. Begitu juga dengan kajian lapangan di Pahang menerusi Projek Dialek di Pahang (DCP-2017-008/2). Dalam menentukan kedominanan dialek Terengganu di sepanjang pantai timur Malaysia, sebelas leksikal daripada 40 leksikal telah dikenal pasti menyamai dialek Terengganu seperti dalam rajah di bawah. Sebelas leksikal yang diuji mengikut pencirian fonologi seperti di atas adalah 'ayam, ikan, durian, sampah, bantal, pukul, ular, panas, tikus, kacau dan serai. Lima pencirian adalah sama seperti pencirian di atas, iaitu:

i) velar nasal di akhir kata

ii) homoganik nasal digugurkan apabila bertemu letupan tidak bersuara

iii) frikatif alveolar $/ \mathrm{s} / \mathrm{kepada} / \mathrm{h} /$

iv) likuida $/ 1 /$ dan $/ \mathrm{r} /$ digugurkan di akhir kata

v) perubahan diftong kepada monoftong. 


\begin{tabular}{|c|c|c|c|c|c|c|c|c|c|c|c|c|}
\hline \multirow[b]{2}{*}{ NEGERI } & \multirow{2}{*}{ NAMA KAMPUNG/DAERAH } & ayam & ikan & durian & sampah & bantal & pukul & ular & panas & tikus & kacau & serai \\
\hline & & [ajar]] & [ikan] & [duyijan $n]$ & [sapah] & [bata] & [puko] & [ulo] & [panah] & [rikuh] & [kựa] & [sәyа] \\
\hline \multirow{26}{*}{ PAHANG } & KUANTAN & & & & & & & & & & & \\
\hline & Kg. Nadak & ajay & ikan & & sapah & & puko & ulo & panah & tikuh & kuţa & səya \\
\hline & Kg. Kuala Reman & & & & sapah & & puko & ulo & panah & tikuh & kuţa & səya \\
\hline & Kg. Permatang Badak & ajan & ikay & duyijan & sapah & & & ulo & panah & & & soya \\
\hline & Kg. Balok Baru & & ikay & & sapah & & puko & ulo & panah & tikuh & kuţa & səya \\
\hline & Kg. Peramu & ajay & ikan & duyijan & sapah & & & ulo & panah & & & soya \\
\hline & Kg. Pantai Beserah & ajay & ikay & & sapah & & puko & ulo & panah & & & soya \\
\hline & PEKAN & & & & & & & & & & & \\
\hline & $\mathrm{Kg}$. Serandu & ajan & & & sapah & & & ulo & panah & & kuţa & səya \\
\hline & Kg. Padang Polo & ajan & & & sapah & & & ulo & panah & & kuţáa & səya \\
\hline & Kg. Bukit Udang & & ikan & duyijan & sapah & & puko & ulo & panah & & kuţa & sәya \\
\hline & Kg. Pelak & ajay & ikan & & sapah & & puko & ulo & panah & & kuţa & səya \\
\hline & $\mathrm{Kg}$. Belimbing & ajay & ikan & & sapah & & & ulo & panah & & kuţa & səya \\
\hline & Kg. Salong & ajan & ikan & duyijan & sapah & bata & & ulo & panah & & & soya \\
\hline & Kg. Batu 5, Sungai Miang & & & duyijan & sapah & & & ulo & panah & & kuţa & soya \\
\hline & Kg. Jambu & ajay & ikay & & sapah & & puko & ulo & panah & & kuţa & soya \\
\hline & Kg. Tering & & ikan & & sapah & & & ulo & panah & & & səya \\
\hline & ROMPIN & & & & & & & & & & & \\
\hline & Kg. Bukit Ibam & ajay & ikay & duyijan & sapah & bata & & ulo & panah & & kutga & səya \\
\hline & Kg. Lanjut & & ikay & & sapah & & & ulo & panah & & & soya \\
\hline & Kg. Tanjung Gemok & ajan & & & sapah & bata & & ulo & panah & & kutga & soya \\
\hline & Kg. Tanjung Gading & ajan & ikan & & sapah & & puko & ulo & panah & & & səya \\
\hline & Kg. Bangkong & ajan & ikan & & sapah & & puko & ulo & panah & & & səya \\
\hline & Kg. Lubuk Batu & ajan & ikan & & sapah & & & ulo & panah & & & sәya \\
\hline & Kg. Janglau 3 & & & & sapah & bata & puko & ulo & panah & & kuţa & \\
\hline & Kg. Sabak & & ikay & & sapah & bata & puko & ulo & panah & tikuh & kựa & \\
\hline \multirow{5}{*}{ JOHOR } & MERSING & & & & & & & & & & & \\
\hline & $\mathrm{Kg}$. Belukar Juling & ajay & ikan & duyijay & sapah & bata & & & panah & & kutga & səya \\
\hline & Kg. Penyabong & ajan & ikan & duyijan & sapah & & puko & ulo & panah & & kuţá & sәyа \\
\hline & KOTA TINGGI & & & & & & & & & & & \\
\hline & Kg. Semayong & & ikan & & sapah & bata & & ulo & panah & & & səya \\
\hline
\end{tabular}

RAJAH 2. Senarai Leksikal Bercirikan Dialek Terengganu

Dari data yang ditemui di Johor dan Pahang, kemudian diselaraskan dengan data dari Terengganu sendiri, kita boleh plotkan dalam peta menggunakan ArcGis. Di bawah adalah rantaian dialek Terengganu yang dominan di sepanjang pantai timur.

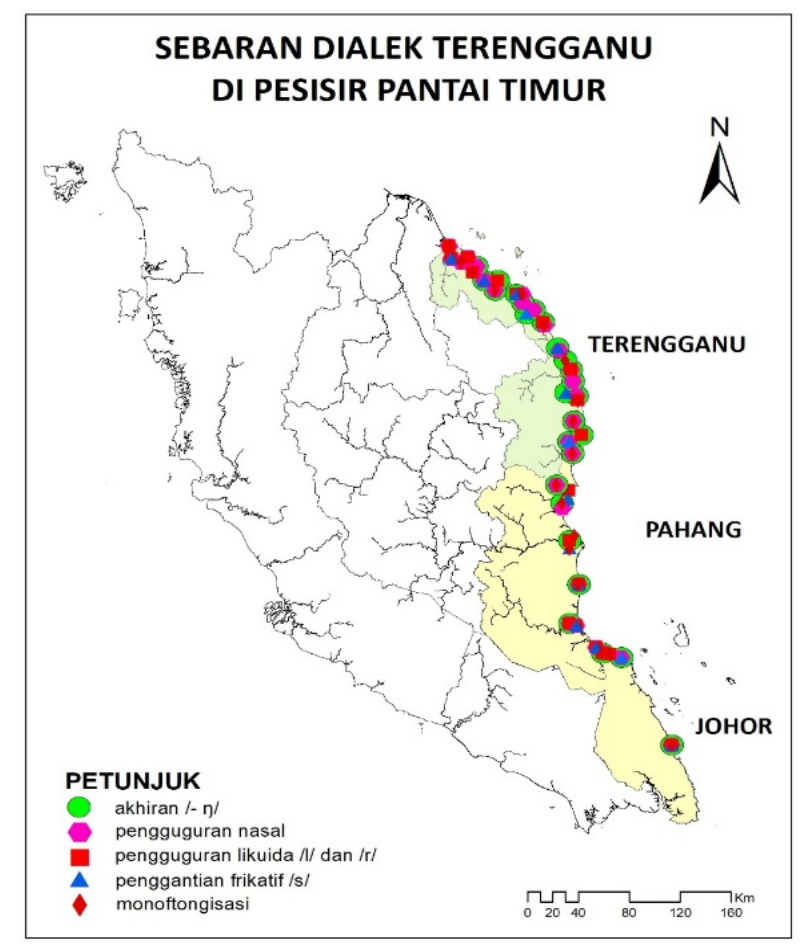

PETA 8. Taburan Dialek Ciri Terengganu di Pesisir Pantai Timur (Nor Hashimah et al., 2021) 
Dalam peta di atas, kajian ini telah dapat memberi penjelasan khusus tentang dakwaan Ajid (2008) mengenai rantaian dialek yang wujud di pantai timur. Kajian Ajid hanya memberikan ciri dialek Terengganu tanpa memberikan contoh jelas dan memberikan plot rantaian tersebut. Kajian ini bukan sahaja mampu memberikan senarai leksikal yang memenuhi pencirian dialek Terengganu malah dapat menentukan titik kampung yang memang menggunakan dialek Terengganu. Rantaian dialek bermula dari Setiu Laut hingga ke Kota Tinggi, Johor.

\section{FAKTOR BUKAN LINGUISTIK}

Dalam kajian geolinguistik, faktor-faktor bukan linguistik menjadi faktor penguat kepada penjelasan penyebaran sesuatu dialek. Penemuan batu bersurat di Hulu Terengganu, dengan tanggal 702 Hijrah (bersamaan 1303 Masihi) terpahat padanya telah menunjukkan bahawa masyarakat Terengganu sudah berubah dan maju satu tahap lagi dengan penerimaan tamadun baru iaitu Islam yang telah bertapak paling lewat sejak awal abad ke 14, menjadikan Terengganu sebagai salah sebuah negeri yang paling awal menerima Islam di Malaysia. (Abdullah Rahman Embong, 2012). Ini diperkukuhkan dengan dakwaan Muhammad Abu Bakar (2018) yang mengatakan bahawa kurun ke-14, muncul komuniti manusia di Kuala Berang, sebuah pelabuhan dan pusat perdagangan, dengan ciri-ciri maritim dan kosmopolitannya, sehingga membawa kepada peristiwa Batu Bersurat. Maka dakwaan ini boleh menjawab mengapa Hulu Terengganu mempunyai sub dialek tersendiri daripada pesisir Terengganu. Kecemerlangan Hulu Terengganu pada abad ke 14 pasti mempunyai bahasa persuratan tersendiri yang gah sesuai dengan kedudukan sebagai kota kosmopolitan. Selain itu, penemuan gendang Dong Son berusia 2000 tahun di Batu Buruk dan Jertih, sebagaimana penemuan pecahan tempayan dan pasu di Kenyir di Hulu Terengganu, menunjukkan kehadiran manusia pra sejarah di kawasan berkenaan yang berkemungkinan berhubungan dengan China dan Vietnam yang sekali gus membuktikan kemetropolitannya Hulu Terengganu.

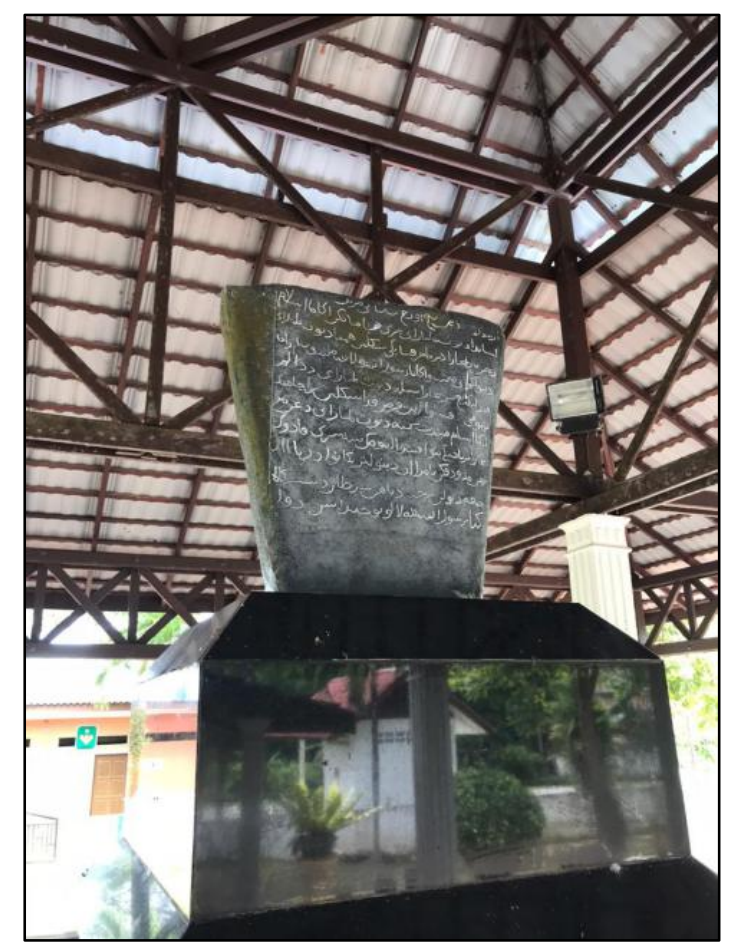

RAJAH 3. Batu Bersurat di Terengganu Kuala Berang 
Berdasarkan penemuan-penemuan ini, jelas menunjukkan faktor sejarah di Terengganu mempunyai peradaban yang tinggi sehingga menjadi tarikan daripada orang luar masuk untuk menetap di Terengganu. Faktor sejarah juga telah menjelaskan bagaimana Besut dan sebahagian Setiu menuturkan dialek Kelantan yang telah pun dijelaskan di atas. Soalan seterusnya, bagaimana pula rantaian dialek berlaku sehingga membolehkan dialek Terengganu tersebar luas dari Setiu Laut sehingga ke Kota Tinggi. Masyarakat Terengganu sangat terkenal sebagai pelaut, malah menjadi rujukan negeri-negeri jiran. Ini diakui oleh sarjana barat seperti Sheppard (1980) bahawa Terengganu juga dikenali sebagai pelayar dan pelaut yang handal. Kehandalan ini membawa mereka merantau ke negeri jiran dan secara tidak langsung menyebarkan sekali dialek mereka. Peta di atas membuktikan kehadiran dialek Terengganu yang boleh dikatakan dominan di pantai timur (Nor Hashimah Jalaluddin et al., 2021).

\section{KESIMPULAN}

Kajian ini telah menyorot kajian Asmah Hj. Omar (1985) selepas 35 tahun. Hasil sorotan kajian telah memberikan input baharu kepada pengkajian dialek di Malaysia. Kini deskripsi mengenai dialek Terengganu lebih tersusun dan sistematik dengan adanya aplikasi ArcGis dan huraian geolinguistik. Pencirian dialek Terengganu kekal sebagaimana yang dikemukakan oleh Asmah (1985) dengan penambahan beberapa senarai leksikal dan pengemasan rumus fonologinya, pemetaan isoglos yang lebih jelas dan akhirnya pembuktian kedominanan dialek Terengganu di sepanjang pantai timur telah turut dapat dibuktikan melalui peta dan maklumat bukan linguistik. Kesemua objektif yang ingin dicapai dalam artikel ini berjaya diketengahkan.

Sorotan kajian bukan bertujuan meremehkan kajian sarjana terdahulu, malah telah menambah baik dengan input baharu. Pendekatan yang lebih terkini dengan penggunaan teknologi ArcGis telah memugarkan kajian dialek di Terengganu khasnya malah kajian dialek di Malaysia amnya. Satu ruang lagi yang perlu diberikan perhatian adalah kekentalan jati diri penutur Terengganu mempertahankan dialeknya. Kajian Nor Hashimah, Siti Noraini \& Harishon (2020) membuktikan berlaku perubahan penggunaan dialek dalam kalangan remaja di Perak yang beransur-ansur menggunakan bahasa standard. Adakah hal yang sama turut berlaku pada dialek golongan remaja Terengganu adalah satu aspek yang menarik untuk dikaji.

\section{PENGHARGAAN}

Kajian ini adalah FRGS/1/2019/SSI01/UKM/01/1, Pemprofilan dan Inovasi Baharu Dialek Melayu Terengganu Berasaskan Teknologi.

\section{RUJUKAN}

Abdullah Rahman Embong (penyt.). (2012). Terengganu Merentasi Tiga Abad: Kesultanan, Politik, Ekonomi, Agama, dan Budaya. Yayasan Diraja Sultan Mizan.

Abdullah Zakaria. (1984). Terengganu, dahulu dan sekarang. Kuala Lumpur: Persatuan Muzium Negara, Muzium Negara.

Ajid Che Kob. (2008). Subklasifikasi dialek Melayu Patani-Kelantan-Terengganu: Satu analisis Kualitatif. Jurnal Melayu, 3,19-51.

Asmah Haji Omar. (1976). The Phonological Diversity of the Malay Dialects. Kuala Lumpur: Dewan Bahasa dan Pustaka

Asmah Haji Omar. (1985). Susur Galur Bahasa Melayu. Kuala Lumpur: Dewan Bahasa dan Pustaka.

Asmah Haji Omar. (2008). Susur Galur Bahasa Melayu cetakan kedua. Kuala Lumpur: Dewan Bahasa dan Pustaka. 
Bloomfield, L. (reprinted). (1950). Language. London, George Allen \& Unwin Ltd.

Collins, J.T. (1983). Dialek Hulu Terengganu. Monograf 8, Fakulti Sains dan Kemanusiaan, UKM. Bangi: Penerbit Universiti Kebangsaan Malaysia.

Collins, J.T. (1996). Khazanah Dialek Melayu. Kuala Lumpur: Dewan Bahasa dan Pustaka.

DCP-2017-008/2. Pelestarian Dialek dan Gastronomi Melayu di Pahang Darul Makmur Menggunakan Pendekatan Sistem Maklumat Geografi (Geographic Information System).

Fazal Mohamed Mohamed Sultan dan Amir Imran Jamil. (2019). Variasi leksikal dialek Melayu di negeri Kedah: Kajian geolinguistik. Geografia-Malaysian Journal of Society and Space, 15(4), 16-29.

Fukushima, C. (2016). Tracing real and apparent time language changes bycomparing linguistic maps. Dlm Marie-Hélène Côté, Remco Knooihuizen \& John Nerbonne (Pnyt.), The future of dialects (hlm. 363-376). Berlin: Language Science Press.

Hersey dan Blanchard, P. (1996). Great ideas revisited: Revisiting the life-cycle theory of leadership Ken Training \& Development. Pro Quest, 50(1), 42-47.

Hoang Thi Châu. (1989). Tiếng Viêt trên c̣ ác miền đết nước: Phương ngữ hoc̣ [Vietnamese of each region: Dialectology]. Nhà xuất bản Khoa hoc X̣ ãhôi, Hà Nôi, Vị êt Nam.

Ismail Hussin. (1973). The Malay dialects in the Malay Peninsular. Nusantara, 3,69-79.

Masaaki, S. (2016). A Phonological Basis for Rethinking Vietnamese Isoglosses - Third ICAG -2016 23 - 24 May 2016, Royal University of Phnom Penh.

Mitsuaki, E. (2018). Correlation between onset and vowels and the principle of "wider distribution" as revealed in the changing process of the forms of "rain" in Tai- Kadai $\mathrm{dlm}$ Fourth International Conference of Geolinguistics Proceedings, Depok, Indonesia.

Mohd Tarmizi Hasrah, Shahidi A. H. \& Rahim Aman. (2013). Inovasi dan Retensi dalam Dialek Hulu Tembeling. GEMA Online ${ }^{\circledR}$ Journal of Language Studies, 13(3), 211-222.

Muhammad Abu Bakar (penyt.). (2018). Orang Terengganu: Asal Usul, Arus Hidup, Arah Tuju. Perbadanan Perpustakaan Awam Terengganu.

Nasrun Alias \& Collins, J.T. (2017). Pendokumentasian Dialek Ulu Terengganu sebagai wahana komunikasi : Satu Tinjauan Awal Aspek Morfologi. Jurnal Melayu, 436-457.

Nor Hashimah Jalaluddin, Norlisafina Sanit, Zaharani Ahmad \& Harishon Radzi. (2016). Variasi Kata Ganti Nama Dialek di Pesisir Sungai Perak: Analisis Geographical Information System (GIS). GEMA Online ${ }^{\circledR}$ Journal of Language Studies, 16(1), 109123.

Nor Hashimah Jalaluddin, Maizatul Hafizah Abdul Halim, Harishon Radzi, \& Junaini Kasdan. (2017). Penyebaran dialek Melayu di Langkawi: Analisis Geolinguistik. GEMA Online ${ }^{\circledR}$ Journal of Language Studies, 17(4), 159-178.

Nor Hashimah Jalaluddin, Adriana Santa Tinggom, Siti Noraini Hamzah, \& Hayati Lateh. (2019). Penyebaran Dialek Melayu Satun di Langkawi dan di Thai: Satu Kajian Perbandingan Berasaskan Geographical Information System (GIS). GEMA Online ${ }^{\circledR}$ Journal of Language Studies, 19(1), 77-96.

Nor Hashimah Jalaluddin, Siti Noraini Hamzah \& Harishon Radzi. (2020). Dialektologi dan GIS. Bangi: Penerbit UKM.

Nor Hashimah Jalaluddin, Wan Athirah Adilah Wan Halim \& Khairul Ashraaf Saari. (2021). The Continuum of Terengganu Dialect along the East Coast Malaysia: A Geolinguistic Study. Journal of Nusantara Studies, 6(1), 176-198.

Normaliza Abd Rahim, Noraien Mansor, \& Noor Rohana Mansor. (2014). Perbualan Masyarakat Daerah Kuala Terengganu. Journal of Business and Social Development, 2(1), 49-56.

Nur Adibah Hasan \& Sharifah Raihan Syed Jaafar. (2017). Struktur Suku Kata Terbitan Dialek Terengganu. Akademika, 87(1), 165-175. 
Pejabat Tanah dan Daerah Besut. (2012). Sejarah Besut. Diakses pada 1 Disember 2020, dari http://pdtbesut.terengganu.gov.my/.

Shahidi A.H. \& Mumad Che Laeh. (2020). Pemanjangan Konsonan dalam Dialek Melayu Patani. GEMA Online ${ }^{\circledR}$ Journal of Language Studies, 20(3),181-198.

Sheppard, M. (1980). Mekarnya seni pertukangan Malaysia. Aziz A. (trans). Eastern Universities Press.

Sibler, P., Weibel, R., Glaser, E., \& Bart G. (2012). Cartographic visualization in support of dialectology. Presentation at the 2012 AutoCarto international symposium on automated cartography, Columbus, September 16-18.

Sperber, D. \& D. Wilson. (1995). Relevance Theory: Communication and Cognition (2 ${ }^{\text {nd }}$ edition). Oxford: Blackwell.

Suzuki, H. (2012). Tibetan pigs revisited: Multiple piglets with a sow in Yunnan Tibetan and beyond -. The 1st International Conference of Asian Geolinguistics, 14 -15 December 2012 Aoyama Gakuin University.

Thompson, G. \& Robert P.V. (2009). Situational leadership theory: A test of three versions, The Leadership Quarterly, 20, 837-848.

Zaharani Ahmad. (1993). The Phonology and Morphology of the Perak Dialect. Kuala Lumpur: Dewan Bahasa dan Pustaka.

Zaharani Ahmad, Nor Hashimah Jalaluddin \& Yusmaniza Yusoff. (2018). GIS Mapping of Dialect Variation in North Perak. Dialectologia, 20,1-20.

\section{PENULIS}

Nor Hashimah Jalaluddin (Ph.D) adalah Profesor di Program Linguistik, Pusat Kajian Bahasa dan Linguistik, Fakulti Sains Sosial dan Kemanusiaan, UKM. Beliau mengkhusus dalam bidang semantik, pragmatik dan geolinguistik. Penyelidikan beliau tertumpu kepada nahu dan korpus, pemikiran Melayu dan pemetaan dialek Melayu berasaskan GIS.

Wan Athirah Adilah adalah pelajar sarjana yang sedang menjalankan penyelidikan tentang Pemprofilan Dialek Terengganu di bawah penyeliaan Prof. Dr. Nor Hashimah. Artikel ini adalah sebahagian daripada dapatan kajian lapangannya.

Harishon Radzi (Ph.D) adalah pensyarah di Program Linguistik. Beliau adalah salah seorang ahli daripada projek ini. Kepakaran beliau adalah dalam bidang geolinguistik. Beliau banyak menjalankan penyelidikan dialek di negara ini. 